\title{
Identification of host genes that affect acquisition of an integrative and conjugative element in Bacillus subtilis
}

\author{
Christopher M. Johnson and Alan D. Grossman * \\ Department of Biology, Massachusetts Institute of Technology, Cambridge, MA 02139
}

\section{Summary}

Conjugation, a major type of horizontal gene transfer in bacteria, involves transfer of DNA from a donor to a recipient using donor-encoded conjugation machinery. Using a high throughput screen (Tn-seq), we identified genes in recipients that contribute to acquisition of the integrative and conjugative element ICEBs 1 by Bacillus subtilis. We found that null mutations in some genes caused an increase, and others a decrease in conjugation efficiency. Some mutations affected conjugation only when present in recipients. Other mutations affected conjugation when present in donors or recipients. Most of the genes identified are known or predicted to affect the cell envelope. Several encode enzymes involved in phospholipid biosynthesis and one encodes a homolog of penicillin binding proteins. Two of the genes identified also affected conjugation of Tn916, indicating that their roles in conjugation may be general. We did not identify any genes in recipients that were essential for ICEBsl conjugation, indicating that if there are such genes, then these are either essential for cell growth or redundant. Our results indicate that acquisition of ICEBs 1 , and perhaps other conjugative elements, is robust and not easily avoided by mutation and that several membrane-related functions affect the efficiency of conjugation.

\section{Introduction}

Bacteria are able to exchange genetic material with their peers. Conjugation, a prevalent type of horizontal gene transfer, is a contact-dependent process in which one bacterium, the donor, transfers genetic material into a recipient, often another bacterium, generating a transconjugant. Conjugation helps drive microbial evolution, allowing recipients to acquire genes from other lineages, enabling the acquisition of new traits and promoting adaptation to new niches and various stresses (reviewed in Frost et al., 2005; Juhas et al., 2009; Norman et al., 2009; Wozniak \& Waldor, 2010).

Of the two main types of conjugative elements, conjugative plasmids are the most widely studied, but integrative and conjugative elements (ICEs) appear to be the most prevalent (Guglielmini et al., 2011). Conjugative elements encode proteins that comprise the mating machinery that is needed for transfer from donor to recipient. With a few exceptions (e.g., Streptomycete conjugation systems, te Poele et al., 2008), the proteins that mediate conjugation are homologous across different elements and are components of type IV

*Corresponding author: Department of Biology, Building 68-530, Massachusetts Institute of Technology, Cambridge, MA 02139, phone: 617-253-1515, fax: 617-253-2643, adg@ mit.edu. 
secretion (T4S) systems. T4S systems are found in Gram negative, Gram positive, and wallless bacteria (Christie et al., 2005; Alvarez-Martinez \& Christie, 2009; Bhatty et al., 2013; Goessweiner-Mohr et al., 2013). Although the mechanisms of conjugative transfer of plasmids and ICEs appear to be conserved, the fates of each element in a host are different. Once acquired, plasmids remain as extrachromosomal autonomously replicating elements. In contrast, ICEs integrate into the host genome and are passively propagated during chromosomal replication, segregation, and cell division (Wozniak \& Waldor, 2010), much like a lysogenic phage.

Most molecular studies of conjugation have focused on functions encoded by the mobile genetic element or its fate in the transconjugant. Although less well studied, genes in the recipient play important roles in conjugation. For example, in Enterococcus faecalis, potential recipients secrete signaling peptides that induce conjugation of certain plasmids (Dunny et al., 1978; Dunny, 2013). Studies with Escherichia coli, Salmonella typhimurium and E. faecalis identified surface components of the recipient that facilitate formation of mating pairs and contribute to conjugation (Watanabe et al., 1970; Skurray et al., 1974; Havekes et al., 1977; Sanderson et al., 1981; Trotter \& Dunny, 1990; Ishiwa \& Komano, 2004; Perez-Mendoza \& de la Cruz, 2009).

ICEBs 1 is an integrative and conjugative element in Bacillus subtilis (Burrus et al., 2002; Auchtung et al., 2005). Genes in ICEBs 1 that are needed for its functions are widely conserved and homologous conjugation genes are found in many conjugative elements, especially in Gram positive bacteria. ICE $B s 1$ can be experimentally induced in $>90^{\circ}$ of cells in a population by overproducing the activator RapI (Auchtung et al., 2005; Auchtung et al., 2007; Lee et al., 2007). Production of active RapI causes derepression of ICEBs 1 gene expression and subsequent excision from the chromosome and assembly of the mating machinery. Conjugation frequencies of approximately $5^{\circ}$ transconjugants/donor are routinely obtained.

We set out to identify genes in recipients that contribute to the successful acquisition of ICEBs 1 via conjugation, and to determine if any such genes were essential for acquisition of ICEBs 1, but not essential for growth. We used transposon mutagenesis followed by highthroughput sequencing, Tn-seq (reviewed in van Opijnen \& Camilli, 2013), to identify candidate genes. We generated a large pool of transposon insertion mutants and used this pool as a recipient population in conjugation, selecting for transconjugants that obtained ICEBs 1 . The location and frequency of individual insertion mutations in the transconjugant pool were determined by high-throughput sequencing. Candidate genes were then tested individually for effects on conjugation.

We identified several genes in recipients that contribute to conjugation, although none were essential for acquisition of ICEBs 1. Deletion of some of the genes caused an increase, whereas deletion of others caused a decrease in conjugation efficiencies. Most of the identified genes encode products that are associated with synthesis of the cell envelope and many of these synthesize or modify the phospholipid head groups of the lipid bilayer. Several mutants were altered in the ability to acquire a plasmid that was mobilized by the ICEBs 1 conjugation machinery, indicating that the effects were likely on DNA transfer and 
not on functions in recipients that are specific to the ICE life cycle. Some of the mutations also caused a conjugation phenotype in the donor. Some mutations also affected conjugation of Tn916, indicating that the screen identified genes generally involved in conjugation, not just those specific for ICEBs 1 .

\section{Results and Discussion}

\section{Rationale and generation of a library of transposon insertions}

We constructed a library of random transposon insertion mutations in B. subtilis and used the mutants as recipients in conjugation with ICEBs 1 . We reasoned that if a gene made a positive contribution to (stimulated) acquisition of ICEBs 1 by a recipient, then insertion mutations in that gene would be under-represented in a library after selection for transconjugants. Conversely, if a gene made a negative contribution to (inhibited) conjugation, then mutations in that gene would be over-represented. We expected most genes to be neutral. We used high-throughput sequencing to determine the frequency with which each gene in the chromosome was interrupted in the population of transconjugants and compared this frequency to that of several different controls. We then made defined null mutations in candidate genes and tested them for effects on conjugation.

We made the insertion library in vitro using $B$. subtilis genomic DNA from a strain that lacks ICEBs 1 (JMA222), the hyperactive C9 mutant of the Himar1 transposase MarC9 (Lampe et al., 1999), and a modified version (magellan6x; Experimental Procedures) of the magellan6 transposon (van Opijnen et al., 2009). We introduced the library of insertion mutations by natural transformation into a $B$. subtilis strain cured of ICEBsI (JMA222) and selected for the transposon-encoded spectinomycin resistance. We recovered approximately $3.85 \times 10^{5}$ transformants containing approximately $1.65 \times 10^{5}$ unique transposon insertions (Experimental Procedures). A pool of these insertion mutants represented the insertion library.

\section{Using the insertion mutants as recipients in conjugation}

We used the insertion library as the recipient population in conjugation with an ICEBs 1 donor strain (KM250) (Menard \& Grossman, 2013). In this donor, ICEBsl is activated in $>90^{\circ}$ of cells following overproduction of the regulator RapI from a xylose-inducible promoter (Pxyl-rapI). Conjugation efficiencies of $\sim 5^{\circ}$ transconjugants per donor are routinely obtained. Following conjugation, we selected for transconjugants (kanamycin and spectinomycin resistance) and separately selected for the recipient population (spectinomycin resistance), irrespective of acquisition of ICEBs 1 , allowing us to directly compare the recipient and transconjugant populations present after conjugation. This comparison should minimize detection of changes in insertion frequencies due to the mating conditions and not due to conjugation per se. We also did mock matings to determine if the mating conditions had effects on growth and survival of potential recipients, independently of conjugation (see below). For each mating or mock mating, cells were collected and pooled for sequencing. We recovered approximately $7 \times 10^{7}$ independent colonies from each pool of interest, ensuring high coverage of the insertion library. 


\section{Identification of candidate genes}

We initially identified 19 candidate genes (Table 1) in transconjugants that appeared to affect acquisition of ICEBs 1 . We first determined the site of the transposon insertion in approximately $7 \times 10^{6}$ mutants in each of the transconjugant and control populations by deep sequencing of genomic DNA (Experimental Procedures) and mapping the site of each insertion in the B. subtilis chromosome using Bowtie \{http://bowtie-bio.sourceforge.net/ index.shtml\} (Langmead et al., 2009). We found that approximately $86^{\circ}$ of the sequence reads mapped to a unique site on the chromosome without any mismatches or ambiguities. Then, for each pool, we determined the frequency of insertion for each open reading frame in the B. subtilis genome by counting the number of insertions in that open reading frame and dividing by the total number of insertions in that pool.

All but one of the 19 candidate genes were initially identified as having at least a 2-fold change in the insertion frequency in the transconjugant population compared to all of the control recipient populations. Genes with altered frequencies of insertions were most easily visualized by plotting the frequency of insertions in each individual gene for the transconjugant population versus that for a comparison population, with each point representing a single gene (Fig. 1A). As expected, most of the genes had roughly the same frequency of insertions in the transconjugant and control pools and these fell along a diagonal line extending from the origin (Fig. 1). However, several genes were above or below this line, indicating that there were differences in the insertion frequency between pools. In addition to identifying genes with $\geq 2$-fold differences in insertion frequency in the transconjugant population, we visually inspected the insertion data, using the MochiView genome browser (Homann \& Johnson, 2010), looking for unusual patterns of insertion frequency that might not be identified by the criteria described above. In this way, we identified insertions in yon $F$ that appeared to affect the acquisition of ICEBsI (see below).

We also did mock matings to determine if specific aspects of the donors exerted selective pressure on the recipient population. For example, we did parallel mock matings with several different donor strains, including: 1) a conE null mutant (strain MMB963). Loss of conE in ICEBs 1 completely abolishes the ability of ICEBs 1 to transfer via conjugation (Berkmen et al., 2010). 2) a strain that overproduces RapI but is cured of ICEBs I (BOSE985). 3) an ICEBs 1 -cured strain that does not overexpress rapI (JMA222). The mock-mated cells were plated on media selective for the recipient library (spectinomycin resistance). Comparison of the insertion frequencies in each gene in these controls allowed us to determine if any of the indicated types of donor cells had effects on growth and survival of potential recipients, independently of conjugation. Comparison of the various mock and actual mating experiments also provided an indication of noise in the insertion frequencies in the recovered populations.

We found that the manipulations used in the conjugation experiments did not exert detectable selective pressure on the recipient population. When comparing any two control populations to each other (e.g., Fig. 1B), there were genes with a $\geq 2$-fold change to insertion frequency. However, this appeared to be due to stochastic variation between insertion frequencies per gene in each pool of recipients. There was no consistent set of genes that 
was altered. Furthermore, most of the variation in genes with $\geq 2$-fold insertion frequency between any two control comparisons occurred in genes with $<150$ insertions.

Together, our results indicate that: 1) Some of the apparent changes in insertion frequencies were likely due to noise or uncontrolled variables. This was most noticeable for genes with smaller numbers of insertions. For this reason, we excluded most of the genes with $<150$ insertions in each of the sequenced populations. 2) Induction of ICEBs 1 gene expression in the donor, or overproduction of RapI in ICEBs 1 -cured cells, did not exert selective pressure on the recipient (for example, by expression of a fratricidal factor) in a manner that is detectable under the conditions used. 3) Some of the changes in insertion frequencies observed in comparing the transconjugant population to the control (Fig. 1A) were likely due to insertions in genes affecting acquisition of ICEBs 1 .

Some of the candidate genes identified appeared to make positive contributions to acquisition of ICEBs 1 whereas others made negative contributions (Table 1; Fig. 2). For example, there were fewer insertions in $m p r F$ in the transconjugant pool than in the controls (Fig. 2A), indicating that $m p r F$ is normally needed for efficient acquisition of ICEBs 1 and that loss of $m p r F$ caused a decrease in acquisition of ICEBs 1 . The $m p r F$ gene product catalyzes the addition of lysine to phosphatidylglycerol, a phospholipid found in the membrane bilayer (Peschel et al., 2001; Salzberg \& Helmann, 2008). In contrast, there were more insertions in $y f n I$ (also known as ltaSA) in the transconjugant pool than in the controls (Fig. 2B), indicating that wild type $y f n I$ is somehow limiting acquisition of ICEBs $I$ and that loss of $y f n I$ caused an increase in acquisition of ICEBs 1 . The $y f n I$ gene product catalyzes synthesis of lipoteichoic acid in the membrane bilayer (Wormann et al., 2011). By visually inspecting the pattern of insertions, we identified a gene (yon $F)$ with an unusual transposon insertion profile in which insertions at some positions were underrepresented in the transconjugant pool whereas insertions at other positions were not (Fig. 2C). yonF is an uncharacterized gene in the lysogenic phage SPß.

\section{Validation of candidate genes and phenotypes of null mutants}

We made null mutations in the 19 candidate genes and tested each mutant individually for growth and the ability to acquire ICEBs 1 in mating assays (Table 1, Fig. 3). Of the 19 mutants, all but lysA (needed for lysine biosynthesis) grew under the growth conditions used for conjugation. As expected, the lysA null mutant grew in defined minimal medium only if lysine was added, or in rich medium (LB). None of the mutations caused changes in viability under the mating conditions, as measured by the number of recipients recovered from mating experiments (data not shown), consistent with the results from the controls in the original Tn-seq screen.

Mutations in seven of the 19 genes caused reproducible effects on conjugation when the mutation was present in the recipient (Table 1, Fig. 3). None of these mutations completely blocked the ability of cells to acquire ICEBs 1 via conjugation. Rather, each caused either an increase or decrease in acquisition of ICEBs 1 (Fig. 3). Null mutations in yonF gave ambiguous results and yon $F$ was not included in the list of seven. The other 11 null mutations caused little or no detectable effect in these and other assays (see below). We suspect that some of these were spurious candidates, but that some might actually affect 
acquisition of ICEBs 1 and that the frequency of recovery of insertion mutations in Tn-seq experiment might be more sensitive than the conjugation assays.

ugtP, yfnl (ItaSA), ykuC, yvbl, and yvbJ-Null mutations in ugtP, yfnI (ltaSA), ykuC, $y v b I$, and $y v b J$ in recipients each caused an approximately 3-10-fold increase in the acquisition of ICEBs 1 in matings on a solid surface (filter mating) (Fig. 3). The ugtP gene product synthesizes glycolipids of the membrane bilayer (Jorasch et al., 1998). As mentioned above, the $y f n I$ gene product catalyzes synthesis of lipoteichoic acid in the membrane bilayer (Wormann et al., 2011). $y k u C, y v b I$, and $y v b J$ are all uncharacterized. The $y v b J$ mutant had the largest increase in conjugation (Fig. 3). This increase was not due to unexpected acquisition of ICEBs 1 by natural transformation, as deleting comK (thereby preventing competence) had little or no effect on the increased conjugation observed in the yvbJ single mutant (Fig. 3).

Null mutations in $y v b I$ and $y v b J$ caused a similar phenotype on conjugation (Fig. 3). The genes are adjacent and convergently transcribed. Because of their proximity we wondered if their phenotypes were related. To test this we generated a $\Delta(y v b I-y v b J)$ double mutant (CMJ154) and used this as a recipient in a filter mating. Deleting both genes increased the conjugation frequency approximately 14 -fold, similar to the effect of deleting either gene alone (Fig. 3). If the genes were acting independently, then we would expect deletion of both of them to lead to much greater increase in conjugation frequency (10-fold for $y \mathrm{vbJ}$ multiplied by 7 -fold for $y v b I$ ). The results with the $y v b I y v b J$ double mutant indicate that the gene products likely affect conjugation via the same mechanism. Therefore, further analyses included a $y v b J$, but not a $y v b I$ mutant.

mprF and lysA-In contrast to the mutations above, null mutations in $m p r F$ and lysA (in recipients) caused a decrease in acquisition of ICEBs 1 by conjugation by approximately 5 fold and 20-fold, respectively (Fig. 3). As mentioned above, the $m p r F$ gene product is needed for production of lysyl-phosphotidylglycerol found in the membrane (Peschel et al., 2001). The use of lysine to modify phopholipids in the membrane prompted us to analyze the lysA mutant. Examination of the Tn-seq data showed that the absolute number of insertions in lysA in several of the pools was below our cutoff, likely because these mutants were unable to grow under our mating growth conditions. However, lys $A$ contained a lower frequency of insertions in the transconjugant pool than in control pools, supporting the notion that it may make a positive contribution to conjugation.

lys $A$ null mutants are auxotrophic for lysine, but grow at apparently wild type rates in the presence of lysine. In the presence of $40 \mu \mathrm{g} / \mathrm{ml}$ lysine, the lys $A$ mutant had a 20 -fold decrease in conjugation (Fig. 3). Supplementing the growth medium with $100 \mu \mathrm{g} / \mathrm{ml}$ lysine did not change growth of the mutant, but restored conjugation to wild type levels. These results indicate that the lower concentration of lysine was sufficient to support protein synthesis and a normal growth rate, and that the additional lysine was likely used in a nonessential cellular process related to the conjugation phenotype. The additional lysine might be affecting expression of $l y s C$, and the activity of its gene product, aspartokinase II (Lu et al., 1991). Aspartokinase II catalyzes synthesis of L-aspartate 4-phosphate, a precursor in the synthesis of lysine, threonine, isoleucine and methionine. L-aspartate 4- 
phosphate is also a precursor in the synthesis of cell wall peptidoglycan (reviewed in Hutton et al., 2007), and we suspect that altered peptidoglycan synthesis might be affecting conjugation.

Double mutants-We analyzed the ability of $y v b J \mathrm{mprF}$ and $y v b J$ ugtP double mutants to function as recipients. We found that the effects of loss of both $y v b J$ and $m p r F$ were additive. The $y v b J$ single mutant was $\sim 10$-fold better and the $\operatorname{mpr} F$ single mutant was $\sim 5$ fold worse than wild type in acquiring ICEBs 1 . The $y v b J ~ m p r F$ double mutant (strain CMJ174) was $\sim 3$-fold better than wild type at acquiring ICEBs 1 , indicating that these mutations were affecting different pathways and the phenotypes were additive. Combining null mutations of $u g t P$ (single mutant up 3-5-fold, Fig. 2) and $y v b J$ (strain CMJ514) resulted in an $\sim 18$-fold increase in the ability to acquire ICEBs 1 . The double mutant consistently had a stronger phenotype than either single mutant, but the effect was not completely additive.

\section{Mixed culture assays for screening candidate genes}

The mating conditions used to test candidate genes were different from those used for the original screen. For example, the original screen was performed using a pool of recipients with relatively few conjugation mutants and the majority of cells wild type for recipient function. We wondered if candidate genes might have an effect on conjugation frequency in the presence of otherwise wild type cells. To test this we performed matings in which we mixed candidate mutant recipients (dnaJ, ecsB, mprF, pbpA, pcrB, scuA, walH, yfnI, yhgE, yvkN, and a yvbIJ double mutant) with a 10-fold excess of a wild type recipient or used a 1:20 ratio of donor to mutant recipient ( $m p r F, p c r B, w a l H, y f n I, y h g E, y v k N$, and a $y v b I J$ double mutant). All of the mutants tested had the same phenotype in these assays as in the mating assays with individual mutants described above. These experiments did not identify any additional genes in which null mutations caused a conjugation phenotype.

\section{ICEBs1 conjugation in liquid medium}

We also tested the candidate genes for effects on conjugation in liquid medium. Some genes in conjugative elements are more important for conjugation during mating in liquid medium than on a solid surface (filters). Functions more important in liquid matings are often related to cell-cell contact and mating pair formation (Manning et al., 1981; Bradley, 1984; Trotter \& Dunny, 1990; Bensing \& Dunny, 1993). Although the Tn-seq screen was done with mating on filters, there might be null mutations in candidate genes that have a more readily detectable phenotype in liquid medium. In addition, the seven genes that have confirmed phenotypes in filter matings, might have a different phenotype in liquid.

Like many other conjugative elements, ICEBs 1 transferred from donor to recipient in liquid medium. Matings in liquid medium (Experimental Procedures) were done by growing donors and recipients separately in defined minimal medium to mid-exponential phase, mixing equal numbers of donor and recipient cells in fresh medium to a final OD600 of 0.1 and continuing growth for 3 hours with aeration, then spreading on agar plates with selective antibiotics. The mating efficiency in liquid medium (Experimental Procedures) using donors with ICEBs 1 induced by overproduction of RapI and wild type recipients (CMJ161) was 
$0.03^{\circ}\left( \pm 0.05^{\circ}\right)$ transconjugants per donor. This was consistently less efficient than mating on filters $\left(\sim 5^{\circ}\right.$ transconjugants per donor $)$.

We analyzed 18 mutants ( $y v b I$ was omitted, see above) for effects on conjugation in liquid medium. The 12 mutants that did not have a reproducible phenotype in filter matings (Table 1) similarly did not have a reproducible phenotype in liquid matings. Two mutants that caused an increase in mating efficiency in filter matings caused a similar fold-increase in liquid matings, relative to WT: $y f n I(2.3 \pm 1.5$ fold increase in liquid, compare to $2.2 \pm 1.4$ fold increase on filters, Fig. 3$)$ and $y v b J(14.9 \pm 8.9$ fold increase in liquid, compare to $10 \pm$ 5.3 fold increase on filters, Fig. 3). However, several mutants with a phenotype in filter matings had a less pronounced phenotype in liquid matings, relative to wild type recipients; $m p r F, u g t P$, lys $A$ grown with $40 \mu \mathrm{g} / \mathrm{ml}$ lysine and $y k u C$ all caused a $̧$-fold change in conjugation in liquid. These results indicate that the genetic factors that influence conjugation on filters and in liquid are somewhat different, perhaps due to differences in host gene expression under the two different mating conditions. We have not investigated what accounts for these different effects.

\section{Effects of mutations on donor function}

In addition to having effects on acquisition of ICEBs 1 in the recipient, we found that two of the genes identified also had an effect in the donor. We tested the three genes with the largest phenotype on filter matings (lysA, mprF and $y v b J$ ) and generated donor strains with null mutations in these genes. We used these mutant donors in mating experiments with wild type recipients and determined conjugation frequencies, compared to the wild-type donor (Fig. 4). The $y v b J$ mutation did not cause a phenotype in the donor, indicating that its function is specific to the recipient. In contrast, we found that both the $m p r F$ and $l y s A$ mutations reduced conjugation from a donor strain (Fig. 4A) approximately the same amount as the reduction when the mutation was in the recipient. The decreased mating efficiency from the $m p r F$ and $l y s A$ mutant donors was not due to a decrease in stability or excision of ICEBs 1. Stability and excision (Experimental procedures) in the mutants was indistinguishable from that in wild type donors (data not shown).

We found that, where tested, the effects on conjugation efficiency of mating a mutant donor to a mutant recipient were generally additive. We crossed an $m p r F$ mutant recipient (strain CMJ162) with an $m p r F$ mutant donor (strain CMJ127). The mating frequency was reduced $\sim 20$-fold, consistent with additive effects of $\sim 4-5$-fold reduction in both donor and recipient. In a cross between a $y v b J$ mutant recipient (strain CMJ153) and a $y v b J$ mutant donor (strain CMJ186), the increase in mating was indistinguishable from that of the $y b b J$ recipient crossed with a wild type donor, consistent with the finding that there was no effect of $y v b J$ in the donor and indicating that there were no synergistic or compensatory effects.

\section{Effects of genes on mobilization of a plasmid}

Stable acquisition of ICEBs 1 in a transconjugant involves several steps after transfer of ICEBs 1 DNA from the donor. We postulated that the mutants affected acquisition of ICEBs 1 DNA by altering DNA transfer and not by affecting a downstream step (e.g., site- 
specific integration). To test this, we measured the effect of each mutation on the ability of ICEBs 1 to mobilize a co-resident, non-conjugative plasmid, pC194.

We found that the lysA, $m p r F$, and $y v b J$ mutants were altered in ICEBs 1 -mediated mobilization of $\mathrm{pC} 194$. This plasmid is transferred by the ICEBs 1 conjugation machinery, independently of transfer of ICEBs I DNA (Lee et al., 2012). In conjugation assays into wild type and mutant recipients using an ICEBs 1 donor that also carried pC194, we found that $m p r F$ and $y v b J$ affected transfer of both $\mathrm{pC} 194$ and ICEBs 1 to the same degree (Fig. 4B). These results indicate that $m p r F$ and $y b v J$ affect the ICEBs 1 conjugation machinery, or have a general effect on mobile DNA.

The lys $A$ mutant was also affected in acquisition of $\mathrm{pC194}$, but to a lesser degree than acquisition of ICE $B s 1$. This difference was not due to unanticipated transformation. We found that mobilization of $\mathrm{pC} 194$ by ICEBs 1 into a lys A, comK double mutant (incapable of natural transformation) was similar to that of the lys $A$ single mutant (Fig. 4B), supporting the conclusion that lysA has less of an effect on mobilization of pC194 than on conjugation of ICEBs 1 . These results indicate that lysA has pleiotropic effects on conjugation, affecting the transfer process and likely affecting a cytoplasmic function involved in stable acquisition of ICEBs 1 .

\section{Some genes affect conjugation of Tn916}

We wondered if the phenotypes of the $l y s A, m p r F$, and $y v b J$ mutants were specific for transfer mediated by the ICEBs 1 conjugation machinery, or if they affected conjugation of other mobile elements in B. subtilis. To test this we measured conjugation of Tn916 into wild type and mutant recipients. We grew strains to mid-exponential phase in either LB or minimal medium, mixed equal amounts of donors and recipients, allowed mating to occur on filters and then selected for transconjugants on LB agar plates with appropriate selective antibiotics and determined the frequency of conjugation (Fig. 4C, D).

We found that loss of lysA had a minor effect on Tn916 mating, regardless of culture conditions, but that this effect was substantially smaller than the effect on ICEBs I (Figs. 3, 4C, D). Loss of $m p r F$ decreased Tn916 mating when the cells were grown in LB, but not in minimal medium. Lastly, loss of $y v b J$ had no effect on conjugation of Tn916 under either condition. These results indicate that $l y s A$ may have a general effect on conjugation in $B$. subtilis, as might $m p r F$, but that the effect of $y v b J$ is likely specific to ICEBs 1 -mediated transfer.

\section{Most mutations affecting conjugation in the recipient alter membrane-related functions}

In order to become established in a new host, ICEBs 1 DNA crosses the cell membrane of both donor and recipient cells. The seven genes with a phenotype in filter matings (Table 1, Fig. 3) encode proteins that are associated with or involved in the function of the cell membrane. Protein products of $m p r F, u g t P$ and $y f n I$ synthesize or modify the phospholipid head groups of the membrane bilayer (Jorasch et al., 1998; Peschel et al., 2001; Wormann et al., 2011). Intriguingly, all of these use the phospholipid phosphatidylglycerol as a precursor during their synthetic processes. The lys $A$ gene product consumes peptidoglycan precursors 
to synthesize lysine, which, among other things, is used by the $m p r F$ gene product in the synthesis of the phospholipid head group lysyl-phosphotidylglycerol (Pavelka \& Jacobs, 1996; Peschel et al., 2001). The $y v b J$ gene product has been found associated with the cell membrane. The $y v b I, y v b J$ and $y k u C$ gene products are predicted to have transmembrane domains by the Transmembrane hidden Markov model (TMHMM) (Sonnhammer et al., 1998; Eymann et al., 2004; Tjalsma \& van Dijl, 2005). Previous studies have consistently identified cell surface components in both Gram positive (Trotter \& Dunny, 1990) and Gram negative (Watanabe et al., 1970; Skurray et al., 1974; Havekes et al., 1977; Sanderson et al., 1981; Ishiwa \& Komano, 2004; Perez-Mendoza \& de la Cruz, 2009) bacteria that contribute to conjugation efficiency. In agreement with earlier work, the association of the proteins identified in the current study with the cell membrane indicates that the composition of the membrane is a major determinant of the efficiency of conjugation. Additional experiments are required to explore the roles of these proteins and membrane phospholipids in facilitating conjugation.

\section{Characterization of $y v b J$}

Our results indicate that $y v b J$ functions in the recipient to reduce acquisition of ICEBs 1 . This phenotype is consistent with $y v b J$ affecting expression or availability of a ligand for mating pair formation, and that its normal function might be to mask such a ligand, making conjugation less frequent than in the absence of $y v b J$.

$y v b J$ is a gene of unknown function. BLAST searches revealed that it is homologous to $t c a A$ of $S$. aureus. The predicted proteins have $31.40^{\circ}$ similarity and $20.90^{\circ}$ identity using a Needleman-Wunch alignment (Needleman \& Wunsch, 1970). The function of tcaA is not known, but it affects the sensitivity of $S$. aureus to glycopeptide antibiotics, including vancomycin (Maki et al., 2004). We found that a $y v b J$ null mutation had no effect on sensitivity of $B$. subtilis to antimicrobials that target the cell wall, including vancomycin, phosphomycin, penicillin G, ampicillin, and lysozyme (data not shown). Further comparisons revealed that the closest paralogs to $\mathrm{YvbJ}$ in B. subtilis are the penicillin binding proteins (PBPs). We used a Needleman-Wunch algorithm to align YvbJ to PBPs and found that $\mathrm{YvbJ}$ is most similar to PBP4a, having $29.5^{\circ}$ similarity and $17.7^{\circ}$ identity (Fig. 5). Additionally, YvbJ contains sequence motifs found in members of the penicilloyl serine transferases superfamily (Fig. 5), which includes PBPs (Goffin \& Ghuysen, 1998), further supporting the notion that it is related to PBPs.

We tested a $y v b J$ null mutant for several phenotypes associated with loss of known PBPs. There are at least 16 PBPs in B. subtilis (not including YvbJ) and their functions are redundant and overlapping (Sauvage et al., 2008). They are involved in synthesis and degradation of the peptidoglycan (Reviewed in Sauvage et al., 2008), cell elongation and morphology (Shohayeb \& Chopra, 1987; Wei et al., 2003), division (Yanouri et al., 1993), and sporulation (Sowell \& Buchanan, 1983; Daniel et al., 1994; Popham et al., 1999; McPherson et al., 2001). yvbJ mutant cells had a normal appearance as visualized by phase microscopy, indicating that if there was any defect in cell division or morphology, it was not visually obvious. Growth rates appeared normal in minimal and rich (LB) medium, and the sporulation frequency was normal. Additionally, there was no change in the autolysin profile 
of $y v b J$ mutant cells as judged by zymography (data not shown). The cell wall of the $y v b J$ mutant was also sensitive to the same $B$. subtilis autolysins as wild type cells (data not shown), indicating that there is not a severe alteration in the structure of the cell wall.

We also tested whether $y v b J$ was essential in the absence of all four of the known class A (bifunctional transpeptidases/transglycosylases) PBPs in B. subtilis. Loss of the four identified class A PBPs ( $p o n A, p b p D, p b p F, p b p G$ ) is not lethal, leading to the proposal that there might be an unidentified PBP with overlapping function (McPherson \& Popham, 2003). If such a PBP exists, it is not YvbJ. We were able to delete $y v b J$ in a strain otherwise missing $p o n A, p b p D, p b p F, p b p G$.

We tested several other PBP genes for defects in conjugation, both as single mutants and in combination with a $y v b J$ null mutation. We made double mutants with $y v b J$ and $d a c A$, $d a c C$, $p b p A, p b p C, p b p D, p b p H$ and $p o n A$. All the double mutants had the same phenotype with respect to conjugation as the $y v b J$ single mutant, except $d a c A$. Loss of $d a c A$, in recipients, appeared to cause a very modest decrease in conjugation ( $\mathcal{-}$-fold). The dacA yvbJ double mutant appeared to be additive in that the net effect on conjugation was an increase in conjugation that was about $50^{\circ}$ that of the $y v b J$ single mutant. These effects were small and it is difficult to make any definitive interpretation.

Lastly, we performed a second Tn-seq screen in which we used a $y v b J$ null mutant to generate the recipient library. We reasoned that due to the enhanced conjugation of the $y v b J$ recipient, genes that inhibit conjugation might be more easily identified in a $y v b J$ null background. We also thought that if $y v b J$ was redundant with other genes for its role in conjugation, then these genes would be more easily identified in the $y v b J$ null background. We compared the insertion frequency in each gene in the $y \mathrm{vbJ}$ transconjugant pool to a control pool and found that $u g t P, y f n I$ and $y k u C$ showed an increased insertion frequency and $m p r F$ showed a decreased insertion frequency, all approximately equal to that seen in the initial Tn-seq screen with the wild type recipient. These results are consistent with the genetic experiments demonstrating that $u g t P$ and $m p r F$ have a partially additive phenotype with $y v b J$. This screen did not identify any genes with an obvious role in cell wall metabolism as having an effect in a $y v b J$ null recipient but not in an otherwise wild type recipient.

Together, our results indicate that if $\mathrm{YvbJ}$ is a PBP or is involved in peptidoglycan synthesis and degradation, its function might be redundant with other PBPs in these assays (excepting conjugation). It is also possible that $\mathrm{YvbJ}$ is not involved in peptidoglycan biosynthesis and the homology with PBPs is a reflection of its evolutionary history and not its current function.

\section{ICEBs1 does not require host genes that are easily lost}

We identified several genes that alter the efficiency of conjugation. However, we did not identify any single host gene that is essential in the recipient for conjugation. If there are host genes that are required for cells to act as a recipients in conjugation, then these genes are likely redundant or essential for cell viability. This characteristic appears to be common to conjugative elements. A large-scale study examined the ability of plasmid R388 to 
transfer into mutant $E$. coli strains \{including the Keio collection (Baba et al., 2006)\}, but did not identify any mutations that prevent $E$. coli from functioning as a recipient (PerezMendoza \& de la Cruz, 2009). Such limited requirements on the part of ICEBs 1 and other conjugative elements for the host to function as a recipient may minimize the likelihood that a host will be able to resist acquisition of ICEBs 1 by mutation or loss of a particular gene.

\section{Tn-seq is a versatile tool for experimentation in B. subtilis}

The techniques used in this screen are widely applicable to genetic inquiry in B. subtilis and other organisms. The use of in vitro transposition circumvents many shortcomings of in vivo transposition, including the undesirable persistence of vectors used to deliver transposons and/or transposase. Additionally, in vitro transposition, coupled with transformation of naturally competent cells is an efficient way to generate large libraries that can be used for diverse purposes. Different selective pressures can be applied to the library described in this work to screen for genes that contribute to different phenotypes. Alternately, these techniques can be used to make other, large libraries in B. subtilis strains with modified genetic backgrounds in order to answer specific questions.

Tn-seq and analogous approaches have been used in a range of different organisms to study genes essential for growth and genes needed for pathogenesis. Our work indicates that Tnseq can also be applied to study horizontal gene transfer, especially in analyzing the role of recipients. Tn-seq libraries could be used in B. subtilis and other organisms to identify genes that alter acquisition of foreign DNA by conjugation, transduction, or transformation. It will be interesting to see if similar genes affect recipients in other organisms and with other conjugative elements.

\section{Experimental Procedures}

\section{Media and growth conditions}

E. coli cells were grown in $\mathrm{LB}$ medium at $37^{\circ} \mathrm{C}$. B. subtilis cells were grown at $37^{\circ} \mathrm{C}$ in $\mathrm{LB}$ medium or in MOPS buffered $\mathrm{S}_{50}$ defined minimal medium with $0.1^{\circ}$ glutamate (Jaacks $e t$ al., 1989) and required amino acids $(40 \mu \mathrm{g} / \mathrm{ml})$. Arabinose $\left(1^{\circ} \mathrm{w} / \mathrm{v}\right)$ was used as a carbon source in place of glucose. Xylose $\left(1^{\circ} \mathrm{w} / \mathrm{v}\right)$ was added to induce expression of Pxyl-rapI (Bhavsar et al., 2001). Antibiotics were used at the following concentrations for B. subtilis: kanamycin $(5 \mu \mathrm{g} / \mathrm{ml})$, spectinomycin $(100 \mu \mathrm{g} / \mathrm{ml})$, chloramphenicol $(5 \mu \mathrm{g} / \mathrm{ml})$, tetracycline $(10 \mu \mathrm{g} / \mathrm{ml})$, and a combination of erythromycin $(0.5 \mu \mathrm{g} / \mathrm{ml})$ and lincomycin $(12.5 \mu \mathrm{g} / \mathrm{ml})$ to select for macrolide-lincosamide-streptogramin (MLS) resistance. For E. coli, ampicillin was used at $100 \mu \mathrm{g} / \mathrm{ml}$ and isopropyl- $\beta$-D-thiogalactopyranoside (IPTG) at $1 \mu \mathrm{g} / \mathrm{ml}$. Solid growth media contained $1.5^{\circ}$ agar.

Mueller-Hinton medium (Fluka) was used for testing sensitivity of $y \mathrm{vbJ}$ mutants to various antibiotics. Cells for sporulation were grown in Difco sporulation medium (DSM) (Harwood \& Cutting, 1990). 


\section{Strains and alleles}

B. subtilis strains are listed in Table 2. Those with trp phe alleles are derived from JH642 (trpC2, pheA1). ICEBs 1 was activated by overexpression of rapI from the xylose-inducible promoter (Pxyl-rapI) integrated in the chromosome at the non-essential amyE locus. The $a m y E::\{$ Pxyl-rapI $m l s\}$ and amyE::\{Pxyl-rapI cat $\}$ alleles used in this study were generated by following the strategy used to generate amyE::\{Pxyl-rapI spc\} (Berkmen et al., 2010; Menard \& Grossman, 2013), except rapI was inserted into vectors encoding MLS or chloramphenicol resistance rather than spectinomycin resistance. A conjugation-deficient ICEBs 1 was generated using a conE deletion allele. The unmarked conE deletion allele used in this study was previously described (Berkmen et al., 2010).

To test the conjugation phenotype of genes identified in this study, we used previously described mutations or generated null mutations in genes of interest (Tables 1 - 2). Most of the null mutations made for this study are insertion-deletions generated by in vitro Gibson assembly (Gibson et al., 2009) followed by natural transformation of $B$. subtilis. Genomic fragments upstream and downstream of the gene to be deleted were PCR amplified from genomic DNA using appropriate primers. Antibiotic resistance cassettes were amplified from pDG795 ( $\mathrm{mls}$ ) (Guerout-Fleury et al., 1996), pR412-magellan6 ( $\mathrm{spc}$ ) (van Opijnen et al., 2009), pDG364 (cat) (Karmazyn-Campelli et al., 1992). The primers were designed so that the sequence of the genomic fragments overlapped the sequence at one end of the antibiotic resistance cassette. The fragments were joined using Gibson assembly to generate a product in which the antibiotic resistance cassette was flanked by genomic sequence upstream and downstream of the gene of interest, replacing that gene but leaving from 3 to 10 codons at the 5' and 3' ends. This product was amplified by PCR and transformed into naturally competent $B$. subtilis cells and antibiotic resistant transformants were selected. We verified the presence of the antibiotic resistance cassette at the desired genomic location using PCR with one primer to the antibiotic resistance cassette and another primer to chromosomal sequences outside of the region used for cloning. Alternately, to confirm construction of $y v b J 175:: m l s$ we transformed competent cells carrying the $y v b J 153:: s p c$ allele with the Gibson-assembly generated allele and screened for gain of MLS resistance and loss of spectinomycin resistance.

The dispensability of $y v b J$ in select backgrounds was tested by generating strain CMJ375, with null mutations to $p b p D$, $p b p F$, ponA, $y w h E$ and $y v b J$. This strain was constructed using a strategy similar to that used to construct strain DPVB87 (McPherson \& Popham, 2003). DPVB49 was transformed with the immR::cat allele from JMA208, leading to instability of ICEBs 1 and an ICEBs 1 -cured isolate was identified (CMJ327), as previously described (Auchtung et al., 2005). This was transformed with the $y v b J 307:: l o x$-cat allele, in which the cat chloramphenicol resistance gene is flanked by lox sites, which act as targets for the recombinase Cre. The lox-flanked cat cassette was then removed by using the temperaturesensitive cre expression vector pDR244 as previously described (Meisner et al., 2013), yielding strain CMJ353. This strain was transformed with the ponA::spc allele from PS2062, yielding strain CMJ375. A control transformation of CMJ353 with the amyE::spc allele from CMJ161 yielded a similar numbers of transformants. The unmarked $p b p D$ and $y v b J$ deletions were confirmed at each step using PCR. 
We made two different alleles of yonF, $\Delta y o n F 67:: s p c$, and $\Delta y o n F 155:: s p c$. The deletion endpoints in $y o n F$ are the same, but the orientation of the $s p c$ cassette is different in the two alleles.

B. subtilis strain CMJ253 was used to test conjugative transfer of Tn916. CMJ253 was generated by transforming naturally competent cells of strain JMA222 with genomic DNA from strain BS49 (Haraldsen \& Sonenshein, 2003) and selecting for tetracycline resistance associated with Tn916 (from BS49).

\section{Generating mariner transposon insertions in vitro}

We made a library of random transposon insertions in vitro into $B$. subtilis genomic DNA (gDNA) and then transferred this library into $B$. subtilis cells by natural transformation. Transposon insertions from six different reactions were used to generate the library from which candidate genes were identified.

We used a modified version of the magellan6 transposon (van Opijnen et al., 2009), magellan6x in which a restriction site targeted by the B. subtilis BsuM restriction modification system (Jentsch, 1983) has been removed. To generate magellan6x, we digested a fragment of magellan6 from the plasmid pR412-magellan6 (van Opijnen et al., 2009) with SalI and XbaI and ligated this into the backbone of the same plasmid digested with XhoI and SalI. The resulting plasmid, pCJ41, carries a copy of magellan6 that has had 6 base pairs of sequence between the XhoI and SalI sites removed, disrupting these sites.

We prepared MarC9 transposase from an E. coli strain containing plasmid pMalC9, essentially as described (Akerley \& Lampe, 2002). The purified enzyme was used to catalyze transposition of the magellan $6 x$ transposon from $\mathrm{pCJ} 41$, prepared using a plasmid mini kit (Qiagen), into genomic DNA (gDNA) in vitro, using a protocol modified from (van Opijnen \& Camilli, 2010). For one reaction, we mixed $1.3 \mu \mathrm{g}$ pCJ41, $5 \mu \mathrm{g}$ target gDNA, 10 $\mu \mathrm{l} 2 \mathrm{x}$ buffer A ( $2 \mathrm{x}$ buffer A contains $41 \mathrm{mM}$ HEPES pH 7.9, 19 ${ }^{\circ}$ glycerol, $187 \mathrm{mM} \mathrm{NaCl}, 19$ $\mathrm{mM} \mathrm{MgCl} 2,476 \mu \mathrm{g} / \mathrm{ml}$ bovine serum albumin, $3.8 \mathrm{mM}$ dithiothreitol, as per (van Opijnen \& Camilli, 2010), except with reduced bovine serum albumin), added $\mathrm{H}_{2} \mathrm{O}$ to $18 \mu \mathrm{l}$, then added $2 \mu \mathrm{l}$ MarC 9 transposase $(170 \mu \mathrm{g} / \mathrm{ml}$ stock, the concentration of the stock was determined by Bradford assay, Bio-Rad, to give a final transposase concentration of $17 \mu \mathrm{g} / \mathrm{ml})$. We incubated the transposition reaction overnight at $30^{\circ} \mathrm{C}$ and then precipitated the DNA by adding $2 \mu \mathrm{l} 3 \mathrm{M}$ sodium acetate, $\mathrm{pH} 5.2$ and $50 \mu \mathrm{l}$ ice-cold ethanol, incubating at $4^{\circ} \mathrm{C}$ for 20 minutes and centrifuging the mix in a microcentrifuge at $20,000 \times \mathrm{g}$ at $4^{\circ} \mathrm{C}$ for 30 minutes. We removed the supernatant and washed the pellet with $100 \mu \mathrm{l}$ ice-cold $70^{\circ}$ ethanol, centrifuging as above for 15 minutes. We then removed the supernatant and allowed the pellet to dry at $37^{\circ} \mathrm{C}$.

We resuspended the DNA in $2 \mu \mathrm{l}$ 10x buffer B (10x buffer B is $500 \mathrm{mM}$ tris-Cl pH 7.8, 100 $\mathrm{mM} \mathrm{MgCl} 2,10 \mathrm{mM}$ dithiothreitol (van Opijnen \& Camilli, 2010)), $2 \mu \mathrm{l} 1 \mathrm{mg} / \mathrm{ml}$ bovine serum albumin and $11 \mu \mathrm{H}_{2} \mathrm{O}$ and incubated the mix at $37^{\circ} \mathrm{C}$ for 4 hours. To repair the transposon insertion junctions we added $4 \mu \mathrm{l} 2.5 \mathrm{mM}$ dNTPs, $1 \mu \mathrm{l}$ T4 DNA Polymerase (3000 units $/ \mathrm{ml}, \mathrm{NEB}$ ) and incubated for 20 minutes at $12^{\circ} \mathrm{C}$. We then heat inactivated the polymerase at $75^{\circ} \mathrm{C}$ for 15 minutes and cooled the reactions on ice. To repair the nicked 
DNA strands we added $0.2 \mu \mathrm{l} 2.6 \mathrm{mM}$ NAD and $1 \mu \mathrm{l}$ E. coli DNA ligase (10000 units $/ \mathrm{ml}$, $\mathrm{NEB}$ ) and incubated the reaction at $16^{\circ} \mathrm{C}$ overnight.

\section{Competent cell preparation and library transformation}

To prepare competent cells for transformation with the gDNA with the transposon insertions we used an optimized two-step transformation protocol. We grew B. subtilis cells overnight in Base medium ( $61 \mathrm{mM} \mathrm{K}_{2} \mathrm{HPO}_{4}, 44 \mathrm{mM} \mathrm{KH}_{2} \mathrm{PO}_{4}, 3.4 \mathrm{mM}$ trisodium citrate dihydrate, $1^{\circ}$ glucose, $0.1^{\circ}$ potassium glutamate, $22.5 \mathrm{mM} \mathrm{MgSO}_{4}, \mathrm{pH} 7.5$ ) supplemented with $0.02^{\circ}$ casamino acids and auxotrophic requirements with shaking at $37^{\circ} \mathrm{C}$. The next morning we chose a culture that had an OD600 between 1.5 and 2.0, diluted this 1/10 in fresh medium, and continued growth with shaking for 3 hours at $37^{\circ} \mathrm{C}$. We then added $10 \mathrm{ml}$ warm Base medium and continued shaking for 2.5 hours. We centrifuged the bulk of the cells at $4700 \mathrm{x}$ $\mathrm{g}$ for 10 minutes at room temperature, discarded the supernatant and resuspended the pellet in $1 / 10$ volume of the parent culture. We split the competent cell prep into $200 \mu \mathrm{l}$ aliquots and added $10 \mu \mathrm{l}$ in-vitro transposed gDNA ( $2.5 \mu \mathrm{g}$ or approximately half of a single reaction) to each of 12 aliquots in $18 \mathrm{~mm}$ tubes. We incubated transformations on a roller drum at $37^{\circ} \mathrm{C}$ for 90 minutes, added $1 \mathrm{ml}$ warm LB to each tube and continued rotating for 30 minutes. We then plated the cells on LB agar with spectinomycin, selecting for the transposon, and incubated the plates overnight. Colonies with the transposon were washed off the plates and pooled into a single library in $1 \mathrm{x} \mathrm{S}_{50}$ salts + metals, without a carbon source. This approach generated approximately $3.85 \times 10^{5}$ independent clones containing transposon insertions using $30 \mu \mathrm{g}$ of transposed gDNA from six in vitro transposition reactions.

\section{Preparation of DNA and sequencing of transposon insertions}

We sequenced the transposon insertion sites using a protocol modified from that previously described (van Opijnen \& Camilli, 2010) to accommodate the B. subtilis chromosome, which is roughly twice the size of the Streptococcus pneumoniae chromosome, for which the original protocol was designed. We prepared genomic DNA from each of the populations of interest. The inverted repeat sequences of the magellan 6 transposon have been altered to carry a MmeI restriction site. MmeI cleaves DNA outside the recognition sequence, allowing roughly 16 base-pairs of genomic DNA to be attached to the ends of the transposon when digested with MmeI, facilitating mapping of the transposon insertion sites (van Opijnen et al., 2009). Additionally, the barcode to distinguish between samples during multiplexing is encoded on the primer that binds to the transposon inverted repeat, rather than the primer that binds to the adapter. We then used Illumina HiSeq to identify the junctions between each transposon insertion and the host chromosome in the transconjugant and various control populations.

We prepared gDNA from pooled cells using the Qiagen DNeasy Blood and Tissue kit using the protocol for Gram + bacteria. We then precipitated the DNA using sodium acetate, $\mathrm{pH}$ 5.2 and ethanol as above and resuspended the DNA in $50 \mu 10 \mathrm{mM}$ tris- $\mathrm{Cl} \mathrm{pH} \mathrm{8.5.} \mathrm{To} \mathrm{digest}$ gDNA with the restriction enzyme MmeI (NEB) we mixed $6 \mu \mathrm{g}$ gDNA, $3 \mu \mathrm{MmeI}$ (2000 units/ml, NEB), $0.66 \mu \mathrm{l} 32 \mathrm{mM}$ S-adenosylmethionine, $30 \mu \mathrm{l}$ NEB buffer 4 and $\mathrm{ddH}_{2} \mathrm{O}$ to $300 \mu \mathrm{l}$ total volume. We digested the gDNA for 2.5 hours at $37^{\circ} \mathrm{C}$, added 6 units calf 
intestinal phosphatase (NEB) and incubated at $37^{\circ} \mathrm{C}$ for an additional 60 minutes. We then extracted the DNA with $300 \mu \mathrm{l}$ phenol:chloroform:isoamyl alcohol (25:24:1), recovered the aqueous layer and precipitated the DNA with sodium acetate and ethanol. We resuspended the DNA in $27.5 \mu \mathrm{l} 2 \mathrm{mM}$ tris- $\mathrm{Cl} \mathrm{pH} 8.5$ and allowed at least 2 hours at $37^{\circ} \mathrm{C}$ for the pellet to dissolve.

We prepared the DNA adapter by annealing oligonucleotides oCJ25 (5'-GTTCAGAGTT CTACAGTCCG ACGATCACAC NN) and oCJ26 (5'Phos/GTGTGATCGT CGGACTGTAG AACTCTGAAC CTGTC/3'Phos). These were dissolved to $200 \mu \mathrm{M}$ in 1 $\mathrm{mM}$ tris $\mathrm{pH} 8.5$, mixing equal volumes of the oligonucleotides, placing in a $96^{\circ} \mathrm{C}$ heat block for $2 \mathrm{~min}$, the removing the heat block from the heater and letting it cool to room temperature. We then added $2 \mu \mathrm{l}$ of the adapter to the gDNA and added $3.5 \mu \mathrm{l} 10 \mathrm{x}$ T4 DNA ligase buffer (NEB), $1.5 \mu \mathrm{l}$ T4 DNA ligase (400,000 units, ml NEB) and incubated the mixture overnight at $16^{\circ} \mathrm{C}$. We then purified the DNA using a Qiagen PCR purification kit, eluted the sample in $50 \mu \mathrm{l} 10 \mathrm{mM}$ tris- $\mathrm{Cl} \mathrm{pH} 8.5$ and used $2-5 \mu \mathrm{l}$ of this as template in a $50 \mu \mathrm{l}$ PCR reaction with Paltinum Taq DNA polymerase (Invitrogen) for 18-20 cycles according the manufacturers instructions. The DNA was amplified with oligonucleotides oCJ23 (5'AATGATACGG CGACCACCGA GATCTGACAG GTTCAGAGTT CTACAGTCCG A) and oCJ22 (5'- CAAGCAGAAG ACGGCATACG AGATXXXXTG TGTGAGACCG GGGACTTATC ATCCAACCTG T), where XXXX denotes a barcode sequence within the oligonucleotide used to identify each sample during multiplexing.

We electrophoresed the PCR samples on an agarose gel, excised the 128 bp band of interest, recovered the DNA in $14 \mu 10 \mathrm{mM}$ Tris-Cl pH 8.5 with a Qiagen DNA Gel-extraction mini kit. We then used a HiSeq 2000 (Illumina) to sequence the transposon-chromosome junctions using oligonucleotide oCJ24 (5'-GACAGGTTCA GAGTTCTACA GTCCGACGAT CACAC) to obtain the primary sequence and oCJ27 (5'-ACAGGTTGGA TGATAAGTCC CCGGTCTCAC ACA) to obtain the barcode sequences.

The number of total transposon insertions in each site present in the pooled library was approximated by identifying sites that had more than one read mapped to it. Reads were included only if they mapped to a site with no mismatches and mapped to a unique site on the chromosome.

\section{Generating a transposon insertion library in a yvbJ null strain}

We used genomic DNA from the transposon insertion library to transform a $y v b J$ null mutant, essentially generating a library of double mutants between $y v b J$ and every nonessential gene. Genomic DNA was prepared from an aliquot of the pooled library by phenolchloroform extraction and resuspended in $10 \mathrm{mM}$ tris- $\mathrm{Cl} \mathrm{pH} \mathrm{8.5.} \mathrm{Naturally} \mathrm{competent} \mathrm{cells}$ of strain CMJ175 ( $\Delta y \mathrm{v} b J 175:: \mathrm{mls})$ were prepared as above and $20 \times 200 \mu \mathrm{l}$ aliquots were transformed with approximately $40 \mu \mathrm{g}$ of total genomic DNA. Cells were spread on plates selective for both $y v b J$ (MLS) and the transposon (spectinomycin). We recovered approximately $4.9 * 10^{5}$ transformants, enabling us to maintain high complexity in this derived library. 


\section{Mating ICEBs1 on filters}

Filter matings were performed largely as described (Lee et al., 2007). Cells were grown in minimal medium. Donors were induced with $1^{\circ}$ xylose $(w / v)$ for two hours, then mixed with an equal number of recipient cells and collected by vacuum filtration on a mating filter. Filters were placed on a $1.5^{\circ}$ agar plate with $1 x$ Spizizen's salts at $37^{\circ} \mathrm{C}$ for $1-3$ hours. Cells were recovered and plated on LB plates with antibiotics selective for donors, recipients, and transconjugants. Plates that were selective for the donor or recipient did not exclude transconjugants, so the total number of transconjugants was subtracted from the total number of donors when making calculations. Typically the number of transconjugants per donor was a few percent (Table 2).

\section{Mating ICEBs1 into a recipient population with the transposon library}

Filter matings into a recipient pool with the transposon library were performed largely in the same manner as other ICEBs 1 filter matings. Several filter matings were performed in parallel to acquire a sufficient number of transconjants. Cells were pooled after being recovered from the filters, prior to spreading on selective plates.

\section{Mating ICEBs1 in liquid medium}

Cells were cultured and ICEBs 1 was induced in minimal medium as for filter matings. After 2 hours of induction, the OD600 of each culture was determined. The cells were centrifuged and resuspended in fresh medium to an OD600 of 1. Donor and recipient cells (100 $\mu \mathrm{l}$ each) were added to $1.8 \mathrm{ml}$ fresh medium in a $18 \mathrm{~mm}$ test tube and xylose was added to $1^{\circ}(\mathrm{w} / \mathrm{v})$. Matings were placed on a roller at $37^{\circ}$ for 3 hours, at which point they were still in mid exponential growth. Cells were then diluted in 1x Spizizen's salts and plated on selective agar as for filter matings.

\section{Mating Tn916 on filters}

Cells were cultured in minimal medium, as described for ICEBs 1 filter matings, or in LB. When cells reached mid exponential phase equal numbers of donor and recipient cells were added to $5 \mathrm{ml}$ of fresh LB or minimal medium. Cells were then collected on filters, placed on $1.5^{\circ}$ agar plate with $1 x$ Spizizen's salts, incubated at $37^{\circ}$ for 3 hours and plated on selective agar as per ICEBs 1 filter matings.

\section{Real time PCR}

Quantitative real-time PCR (qPCR) was used to measure excision of ICEBs 1 from crude lysates of donor cells. Lysates were prepared and qPCR performed on a Light-Cycler 480 Real-Time PCR system with Syber Green detection reagents (Roche) as previously described (Lee et al., 2010; Menard \& Grossman, 2013). The unoccupied chromosomal attachment site $(a t t B)$ was detected in donor cells and normalized relative to the levels of $\cot F$, a chromosomal gene. Excision frequency was determined by comparing to attB levels to those in an ICEBs 1 null strain in which $100^{\circ}$ of the cells have an unoccupied attB site (JMA222). Genomic DNA from JMA222 was used to generate standard curves. 


\section{ICEBs1 stability}

ICEBs 1 stability was determined in cultures of donor cells in the absence of selective pressure, by measuring the fraction of cells that retained ICEBs 1 after overproduction of RapI for $\times$ hrs and subjected to mock mating. All potential donor cells were selected based on resistance to chloramphenicol (at $a m y E$ ). Individual colonies were then picked and tested for the presence of ICEBs I (kanamycin resistant), enabling determination of the frequency of loss (or retention) of ICEBs 1 in donors following induction under mating conditions.

\section{Antimicrobial sensitivity}

Strains were grown in LB or Mueller-Hinton broth to an OD600 of 0.5, then $300 \mu$ of the cultures were mixed with $3 \mathrm{ml}$ soft agar (LB or Mueller Hinton) at $50^{\circ} \mathrm{C}$ and overlayed on an agar plates (LB or Mueller Hinton) and allowed to solidify. Then $5 \mathrm{~mm}$ filter paper punches, impregnated with $0.5 \mu \mathrm{g}$ vancomycin, $500 \mu \mathrm{g}$ phosphomycin, $0.5 \mu \mathrm{g}$ penicillin $\mathrm{G}$, $10 \mu \mathrm{g}$ ampicillin or $100 \mu \mathrm{g}$ lysozyme (each in $10 \mu \mathrm{l}$ ) were placed on the surface of the plates. The plates were incubated overnight at $37^{\circ}$. The next day the zones of clearing were measured and the diameter of the filter paper subtracted to calculate the zones of inhibition.

\section{Sporulation assays}

Sporulation frequency was determined by as heat-resistant $\left(80^{\circ} \mathrm{C}\right)$ colony forming units (CFUs) as a fraction of total CFUs (Harwood \& Cutting, 1990).

\section{Analysis of autolysins}

Autolysins were extracted with SDS, essentially as described (Foster, 1992). Cells were grown in LB to an OD600 of $\sim 1,50 \mathrm{ml}$ of culture were pelleted, rinsed with 1x Spizizen's salts, then resuspended in $500 \mu \mathrm{l} \mathrm{SDS}-\mathrm{PAGE}$ buffer $\left(50 \mathrm{mM}\right.$ tris- $\mathrm{HCl} \mathrm{pH} 6.8,2^{\circ} \mathrm{SDS}, 10^{\circ}$ $\mathrm{v} / \mathrm{v}$ glycerol, $100 \mathrm{mM}$ dithiothreitol, $0.0025^{\circ} \mathrm{w} / \mathrm{v}$ bromophenol blue). The suspension was boiled for 3 minutes, insoluble material was pelleted by centrifugation and the supernatant containing extracted autolysins was recovered.

We used killed cells as the source of cell wall material for substrate in zymogram assays. Wild type (JMA222) and $y v b J$ mutant (CMJ175) cells were grown in LB medium to an OD600 of 1 . Cells were then pelleted, resuspended in $4^{\circ}$ SDS, killed by boiling for 20 minutes, then washed $3 \times$ with $\mathrm{dH}_{2} \mathrm{O}$.

Samples $(20 \mu \mathrm{l})$ to test for autolysin activity were loaded onto on a $12^{\circ}$ SDS-PAGE gel containing $5^{\circ}(\mathrm{v} / \mathrm{v}$ of a wet pellet) killed cells of the strain of interest, and electrophoresed. The gel was then soaked overnight in renaturation buffer $\left(25 \mathrm{mM}\right.$ tris- $\mathrm{HCl}, \mathrm{pH} 8,1^{\circ}$ Triton X-100) (Leclerc \& Asselin, 1989), changing the buffer once. A duplicate gel without heatkilled cells was also prepared and electrophoresed in parallel and stained with Imperial protein stain (Thermo Scientific) to visualize proteins. Gels were photographed and examined visually to identify autolysin bands.

\section{Acknowledgments}

We thank D. Popham for PBP mutant strains, J. Helmann for the ugtP mutant strain, C. Lee and L. Wright for useful discussions, and comments on the manuscript. Research reported here is based upon work supported, in part, 
by the National Institute of General Medical Sciences of the National Institutes of Health under award number R01GM050895. Any opinions, findings, and conclusions or recommendations expressed in this report are those of the authors and do not necessarily reflect the views of the National Institutes of Health.

\section{Literature cited}

Akerley BJ, Lampe DJ. Analysis of gene function in bacterial pathogens by GAMBIT. Methods in Enzymology. 2002; 358:100-108. [PubMed: 12474380]

Alvarez-Martinez CE, Christie PJ. Biological diversity of prokaryotic type IV secretion systems. Microbiol Mol Biol Rev. 2009; 73:775-808. [PubMed: 19946141]

Auchtung JM, Lee CA, Garrison KL, Grossman AD. Identification and characterization of the immunity repressor (ImmR) that controls the mobile genetic element ICEBs 1 of Bacillus subtilis. Mol Microbiol. 2007; 64:1515-1528. [PubMed: 17511812]

Auchtung JM, Lee CA, Monson RE, Lehman AP, Grossman AD. Regulation of a Bacillus subtilis mobile genetic element by intercellular signaling and the global DNA damage response. Proc Natl Acad Sci U S A. 2005; 102:12554-12559. [PubMed: 16105942]

Baba T, Ara T, Hasegawa M, Takai Y, Okumura Y, Baba M, Datsenko KA, Tomita M, Wanner BL, Mori H. Construction of Escherichia coli K-12 in-frame, single-gene knockout mutants: the Keio collection. Mol Syst Biol. 2006; 220060008.

Bensing BA, Dunny GM. Cloning and molecular analysis of genes affecting expression of binding substance, the recipient-encoded receptor(s) mediating mating aggregate formation in Enterococcus faecalis. J Bacteriol. 1993; 175:7421-7429. [PubMed: 8226689]

Berkmen MB, Lee CA, Loveday EK, Grossman AD. Polar positioning of a conjugation protein from the integrative and conjugative element ICEBs I of Bacillus subtilis. J Bacteriol. 2010; 192:38-45. [PubMed: 19734305]

Bhatty M, Laverde Gomez JA, Christie PJ. The expanding bacterial type IV secretion lexicon. Res Microbiol. 2013; 164:620-639. [PubMed: 23542405]

Bhavsar AP, Zhao X, Brown ED. Development and characterization of a xylose-dependent system for expression of cloned genes in Bacillus subtilis: conditional complementation of a teichoic acid mutant. Appl Environ Microbiol. 2001; 67:403-410. [PubMed: 11133472]

Bradley DE. Characteristics and function of thick and thin conjugative pili determined by transferderepressed plasmids of incompatibility groups I1, I2, I5, B, K and Z. J Gen Microbiol. 1984; 130:1489-1502. [PubMed: 6148378]

Burrus V, Pavlovic G, Decaris B, Guedon G. The ICESt1 element of Streptococcus thermophilus belongs to a large family of integrative and conjugative elements that exchange modules and change their specificity of integration. Plasmid. 2002; 48:77-97. [PubMed: 12383726]

Christie PJ, Atmakuri K, Krishnamoorthy V, Jakubowski S, Cascales E. Biogenesis, architecture, and function of bacterial type IV secretion systems. Annu Rev Microbiol. 2005; 59:451-485. [PubMed: 16153176]

Christie PJ, Korman RZ, Zahler SA, Adsit JC, Dunny GM. Two conjugation systems associated with Streptococcus faecalis plasmid pCF10: identification of a conjugative transposon that transfers between S. faecalis and Bacillus subtilis. J Bacteriol. 1987; 169:2529-2536. [PubMed: 3034859]

Daniel RA, Drake S, Buchanan CE, Scholle R, Errington J. The Bacillus subtilis spoVD gene encodes a mother-cell-specific penicillin-binding protein required for spore morphogenesis. J Mol Biol. 1994; 235:209-220. [PubMed: 8289242]

Dunny GM. Enterococcal sex pheromones: signaling, social behavior, and evolution. Annu Rev Genet. 2013; 47:457-482. [PubMed: 24050179]

Dunny GM, Brown BL, Clewell DB. Induced cell aggregation and mating in Streptococcus faecalis: evidence for a bacterial sex pheromone. Proc Natl Acad Sci U S A. 1978; 75:3479-3483. [PubMed: 98769]

Eymann C, Dreisbach A, Albrecht D, Bernhardt J, Becher D, Gentner S, Tam le T, Buttner K, Buurman G, Scharf C, Venz S, Volker U, Hecker M. A comprehensive proteome map of growing Bacillus subtilis cells. Proteomics. 2004; 4:2849-2876. [PubMed: 15378759] 
Foster SJ. Analysis of the autolysins of Bacillus subtilis 168 during vegetative growth and differentiation by using renaturing polyacrylamide gel electrophoresis. J Bacteriol. 1992; 174:464470. [PubMed: 1345911]

Frost LS, Leplae R, Summers AO, Toussaint A. Mobile genetic elements: the agents of open source evolution. Nat Rev Microbiol. 2005; 3:722-732. [PubMed: 16138100]

Gibson DG, Young L, Chuang RY, Venter JC, Hutchison CA, Smith HO. Enzymatic assembly of DNA molecules up to several hundred kilobases. Nat Methods (3rd). 2009; 6:343-345. [PubMed: 19363495]

Goessweiner-Mohr N, Arends K, Keller W, Grohmann E. Conjugative type IV secretion systems in Gram-positive bacteria. Plasmid. 2013; 70:289-302. [PubMed: 24129002]

Goffin C, Ghuysen JM. Multimodular penicillin-binding proteins: an enigmatic family of orthologs and paralogs. Microbiol Mol Biol Rev. 1998; 62:1079-1093. [PubMed: 9841666]

Guerout-Fleury AM, Frandsen N, Stragier P. Plasmids for ectopic integration in Bacillus subtilis. Gene. 1996; 180:57-61. [PubMed: 8973347]

Guglielmini, J.; Quintais, L.; Garcillan-Barcia, MP.; de la Cruz, F.; Rocha, EP. PLoS Genet. Vol. 7. e1002222: 2011. The repertoire of ICE in prokaryotes underscores the unity, diversity, and ubiquity of conjugation.

Guldan H, Matysik FM, Bocola M, Sterner R, Babinger P. Functional assignment of an enzyme that catalyzes the synthesis of an archaea-type ether lipid in bacteria. Angew Chem Int Ed Engl. 2011; 50:8188-8191. [PubMed: 21761520]

Haraldsen JD, Sonenshein AL. Efficient sporulation in Clostridium difficile requires disruption of the sigmaK gene. Mol Microbiol. 2003; 48:811-821. [PubMed: 12694623]

Harwood, CR.; Cutting, SM. Molecular Biological Methods for Bacillus. John Wiley \& Sons; Chichester: 1990.

Havekes L, Tommassen J, Hoekstra W, Lugtenberg B. Isolation and characterization of Escherichia coli K-12 F-mutants defective in conjugation with an I-type donor. J Bacteriol. 1977; 129:1-8. [PubMed: 318634]

Holtmann G, Bakker EP, Uozumi N, Bremer E. KtrAB and KtrCD: two K+ uptake systems in Bacillus subtilis and their role in adaptation to hypertonicity. J Bacteriol. 2003; 185:1289-1298. [PubMed: 12562800]

Homann OR, Johnson AD. MochiView: versatile software for genome browsing and DNA motif analysis. BMC Biol. 2010; 8:49. [PubMed: 20409324]

Hutton CA, Perugini MA, Gerrard JA. Inhibition of lysine biosynthesis: an evolving antibiotic strategy. Mol Biosyst. 2007; 3:458-465. [PubMed: 17579770]

Ishiwa A, Komano T. PilV adhesins of plasmid R64 thin pili specifically bind to the lipopolysaccharides of recipient cells. J Mol Biol. 2004; 343:615-625. [PubMed: 15465049]

Jaacks KJ, Healy J, Losick R, Grossman AD. Identification and characterization of genes controlled by the sporulation-regulatory gene spoOH in Bacillus subtilis. J Bacteriol. 1989; 171:4121-4129. [PubMed: 2502532]

Jentsch S. Restriction and modification in Bacillus subtilis: sequence specificities of restriction/ modification systems BsuM, BsuE, and BsuF. J Bacteriol. 1983; 156:800-808. [PubMed: 6195145]

Jorasch P, Wolter FP, Zahringer U, Heinz E. A UDP glucosyltransferase from Bacillus subtilis successively transfers up to four glucose residues to 1,2-diacylglycerol: expression of ypfP in Escherichia coli and structural analysis of its reaction products. Mol Microbiol. 1998; 29:419-430. [PubMed: 9720862]

Juhas M, van der Meer JR, Gaillard M, Harding RM, Hood DW, Crook DW. Genomic islands: tools of bacterial horizontal gene transfer and evolution. FEMS Microbiol Rev. 2009; 33:376-393. [PubMed: 19178566]

Karmazyn-Campelli C, Fluss L, Leighton T, Stragier P. The spoIIN279(ts) mutation affects the FtsA protein of Bacillus subtilis. Biochimie. 1992; 74:689-694. [PubMed: 1391048]

Lampe DJ, Akerley BJ, Rubin EJ, Mekalanos JJ, Robertson HM. Hyperactive transposase mutants of the Himar1 mariner transposon. Proc Natl Acad Sci U S A. 1999; 96:11428-11433. [PubMed: 10500193] 
Langmead B, Trapnell C, Pop M, Salzberg SL. Ultrafast and memory-efficient alignment of short DNA sequences to the human genome. Genome Biol. 2009; 10:R25. [PubMed: 19261174]

Leclerc D, Asselin A. Detection of bacterial cell wall hydrolases after denaturing polyacrylamide gel electrophoresis. Can J Microbiol. 1989; 35:749-753. [PubMed: 2819603]

Lee CA, Auchtung JM, Monson RE, Grossman AD. Identification and characterization of int (integrase), xis (excisionase) and chromosomal attachment sites of the integrative and conjugative element ICEBs 1 of Bacillus subtilis. Mol Microbiol. 2007; 66:1356-1369. [PubMed: 18005101]

Lee CA, Babic A, Grossman AD. Autonomous plasmid-like replication of a conjugative transposon. Mol Microbiol. 2010; 75:268-279. [PubMed: 19943900]

Lee CA, Thomas J, Grossman AD. The Bacillus subtilis conjugative transposon ICEBs 1 mobilizes plasmids lacking dedicated mobilization functions. J Bacteriol. 2012; 194:3165-3172. [PubMed: 22505685]

Leskela S, Kontinen VP, Sarvas M. Molecular analysis of an operon in Bacillus subtilis encoding a novel $\mathrm{ABC}$ transporter with a role in exoprotein production, sporulation and competence. Microbiology. 1996; 142:71-77. Pt 1. [PubMed: 8581172]

Lu Y, Chen NY, Paulus H. Identification of aecA mutations in Bacillus subtilis as nucleotide substitutions in the untranslated leader region of the aspartokinase II operon. J Gen Microbiol. 1991; 137:1135-1143. [PubMed: 1907638]

Maki H, McCallum N, Bischoff M, Wada A, Berger-Bachi B. tcaA inactivation increases glycopeptide resistance in Staphylococcus aureus. Antimicrob Agents Chemother. 2004; 48:1953-1959. [PubMed: 15155184]

Manning PA, Morelli G, Achtman M. traG protein of the F sex factor of Escherichia coli K-12 and its role in conjugation. Proc Natl Acad Sci U S A. 1981; 78:7487-7491. [PubMed: 7038680]

Mattatall NR, Jazairi J, Hill BC. Characterization of YpmQ, an accessory protein required for the expression of cytochrome c oxidase in Bacillus subtilis. J Biol Chem. 2000; 275:28802-28809. [PubMed: 10837475]

McPherson DC, Driks A, Popham DL. Two class A high-molecular-weight penicillin-binding proteins of Bacillus subtilis play redundant roles in sporulation. J Bacteriol. 2001; 183:6046-6053. [PubMed: 11567005]

McPherson DC, Popham DL. Peptidoglycan synthesis in the absence of class A penicillin-binding proteins in Bacillus subtilis. J Bacteriol. 2003; 185:1423-1431. [PubMed: 12562814]

Meisner J, Llopis P. Montero, Sham LT, Garner E, Bernhardt TG, Rudner DZ. FtsEX is required for CwlO peptidoglycan hydrolase activity during cell wall elongation in Bacillus subtilis. Mol Microbiol. 2013; 89:1069-1083. [PubMed: 23855774]

Menard KL, Grossman AD. Selective pressures to maintain attachment site specificity of integrative and conjugative elements. PLoS Genet. 2013; 9:e1003623. [PubMed: 23874222]

Murray T, Popham DL, Pearson CB, Hand AR, Setlow P. Analysis of outgrowth of Bacillus subtilis spores lacking penicillin-binding protein 2a. J Bacteriol. 1998; 180:6493-6502. [PubMed: 9851991]

Murray T, Popham DL, Setlow P. Identification and characterization of $p b p C$, the gene encoding Bacillus subtilis penicillin-binding protein 3. J Bacteriol. 1996; 178:6001-6005. [PubMed: 8830698]

Needleman SB, Wunsch CD. A general method applicable to the search for similarities in the amino acid sequence of two proteins. J Mol Biol. 1970; 48:443-453. [PubMed: 5420325]

Norman A, Hansen LH, Sorensen SJ. Conjugative plasmids: vessels of the communal gene pool. Philosophical transactions of the Royal Society of London. Series B, Biological sciences. 2009; 364:2275-2289.

Pavelka MS Jr. Jacobs WR Jr. Biosynthesis of diaminopimelate, the precursor of lysine and a component of peptidoglycan, is an essential function of Mycobacterium smegmatis. J Bacteriol. 1996; 178:6496-6507. [PubMed: 8932306]

Pedersen LB, Murray T, Popham DL, Setlow P. Characterization of dacC, which encodes a new lowmolecular-weight penicillin-binding protein in Bacillus subtilis. J Bacteriol. 1998; 180:4967-4973. [PubMed: 9733705] 
Perego M, Hoch JA. Sequence analysis and regulation of the $h p r$ locus, a regulatory gene for protease production and sporulation in Bacillus subtilis. J Bacteriol. 1988; 170:2560-2567. [PubMed: 3131303]

Perez-Mendoza D, de la Cruz F. Escherichia coli genes affecting recipient ability in plasmid conjugation: are there any? BMC Genomics. 2009; 10:71. [PubMed: 19203375]

Peschel A, Jack RW, Otto M, Collins LV, Staubitz P, Nicholson G, Kalbacher H, Nieuwenhuizen WF, Jung G, Tarkowski A, van Kessel KP, van Strijp JA. Staphylococcus aureus resistance to human defensins and evasion of neutrophil killing via the novel virulence factor $\mathrm{MprF}$ is based on modification of membrane lipids with 1-lysine. J Exp Med. 2001; 193:1067-1076. [PubMed: 11342591]

Popham DL, Gilmore ME, Setlow P. Roles of low-molecular-weight penicillin-binding proteins in Bacillus subtilis spore peptidoglycan synthesis and spore properties. J Bacteriol. 1999; 181:126132. [PubMed: 9864321]

Popham DL, Helin J, Costello CE, Setlow P. Analysis of the peptidoglycan structure of Bacillus subtilis endospores. J Bacteriol. 1996; 178:6451-6458. [PubMed: 8932300]

Popham DL, Setlow P. Cloning, nucleotide sequence, mutagenesis, and mapping of the Bacillus subtilis pbpD gene, which codes for penicillin-binding protein 4. J Bacteriol. 1994; 176:71977205. [PubMed: 7961491]

Popham DL, Setlow P. Cloning, nucleotide sequence, and mutagenesis of the Bacillus subtilis ponA operon, which codes for penicillin-binding protein (PBP) 1 and a PBP-related factor. J Bacteriol. 1995; 177:326-335. [PubMed: 7814321]

Salzberg LI, Helmann JD. Phenotypic and transcriptomic characterization of Bacillus subtilis mutants with grossly altered membrane composition. J Bacteriol. 2008; 190:7797-7807. [PubMed: 18820022]

Sanderson KE, Janzer J, Head J. Influence of lipopolysaccharide and protein in the cell envelope on recipient capacity in conjugation of Salmonella typhimurium. J Bacteriol. 1981; 148:283-293. [PubMed: 7026536]

Sauvage E, Kerff F, Terrak M, Ayala JA, Charlier P. The penicillin-binding proteins: structure and role in peptidoglycan biosynthesis. FEMS Microbiol Rev. 2008; 32:234-258. [PubMed: 18266856]

Shohayeb M, Chopra I. Mutations affecting penicillin-binding proteins 2a, 2b and 3 in Bacillus subtilis alter cell shape and peptidoglycan metabolism. J Gen Microbiol. 1987; 133:1733-1742. [PubMed: 3117967]

Skurray RA, Hancock RE, Reeves P. Con- mutants: class of mutants in Escherichia coli K-12 lacking a major cell wall protein and defective in conjugation and adsorption of a bacteriophage. $\mathrm{J}$ Bacteriol. 1974; 119:726-735. [PubMed: 4604263]

Sonnhammer EL, von Heijne G, Krogh A. A hidden Markov model for predicting transmembrane helices in protein sequences. Proc Int Conf Intell Syst Mol Biol. 1998; 6:175-182. [PubMed: 9783223]

Sowell MO, Buchanan CE. Changes in penicillin-binding proteins during sporulation of Bacillus subtilis. J Bacteriol. 1983; 153:1331-1337. [PubMed: 6402492]

Szurmant H, Nelson K, Kim EJ, Perego M, Hoch JA. YycH regulates the activity of the essential YycFG two-component system in Bacillus subtilis. J Bacteriol. 2005; 187:5419-5426. [PubMed: 16030236]

te Poele EM, Bolhuis H, Dijkhuizen L. Actinomycete integrative and conjugative elements. Antonie Van Leeuwenhoek. 2008; 94:127-143. [PubMed: 18523858]

Tjalsma H, van Dijl JM. Proteomics-based consensus prediction of protein retention in a bacterial membrane. Proteomics. 2005; 5:4472-4482. [PubMed: 16220534]

Trotter KM, Dunny GM. Mutants of Enterococcus faecalis deficient as recipients in mating with donors carrying pheromone-inducible plasmids. Plasmid. 1990; 24:57-67. [PubMed: 2125350]

van Opijnen T, Bodi KL, Camilli A. Tn-seq: high-throughput parallel sequencing for fitness and genetic interaction studies in microorganisms. Nat Methods. 2009; 6:767-772. [PubMed: 19767758] 
van Opijnen T, Camilli A. Genome-wide fitness and genetic interactions determined by Tn-seq, a high-throughput massively parallel sequencing method for microorganisms. Curr Protoc Microbiol. 2010 Chapter 1: Unit1E 3.

van Opijnen T, Camilli A. Transposon insertion sequencing: a new tool for systems-level analysis of microorganisms. Nat Rev Microbiol. 2013; 11:435-442. [PubMed: 23712350]

Watanabe T, Arai T, Hattori T. Effects of cell wall polysaccharide on the mating ability of Salmonella typhimurium. Nature. 1970; 225:70-71. [PubMed: 4903100]

Wei Y, Havasy T, McPherson DC, Popham DL. Rod shape determination by the Bacillus subtilis class B penicillin-binding proteins encoded by $p b p A$ and $p b p H$. J Bacteriol. 2003; 185:4717-4726. [PubMed: 12896990]

Wormann ME, Corrigan RM, Simpson PJ, Matthews SJ, Grundling A. Enzymatic activities and functional interdependencies of Bacillus subtilis lipoteichoic acid synthesis enzymes. Mol Microbiol. 2011; 79:566-583. [PubMed: 21255105]

Wozniak RA, Waldor MK. Integrative and conjugative elements: mosaic mobile genetic elements enabling dynamic lateral gene flow. Nat Rev Microbiol. 2010; 8:552-563. [PubMed: 20601965]

Wray LV Jr. Pettengill FK, Fisher SH. Catabolite repression of the Bacillus subtilis hut operon requires a cis-acting site located downstream of the transcription initiation site. J Bacteriol. 1994; 176:1894-1902. [PubMed: 8144455]

Yamamoto J, Shimizu M, Yamane K. Molecular cloning and analysis of nucleotide sequence of the Bacillus subtilis lysA gene region using B. subtilis phage vectors and a multi-copy plasmid, pUB110. Agric Biol Chem. 1991; 55:1615-1626. [PubMed: 1368705]

Yanouri A, Daniel RA, Errington J, Buchanan CE. Cloning and sequencing of the cell division gene pbpB, which encodes penicillin-binding protein 2B in Bacillus subtilis. J Bacteriol. 1993; 175:7604-7616. [PubMed: 8244929]

Zahler SA, Korman RZ, Rosenthal R, Hemphill HE. Bacillus subtilis bacteriophage SPbeta: localization of the prophage attachment site, and specialized transduction. J Bacteriol. 1977; 129:556-558. [PubMed: 401505] 

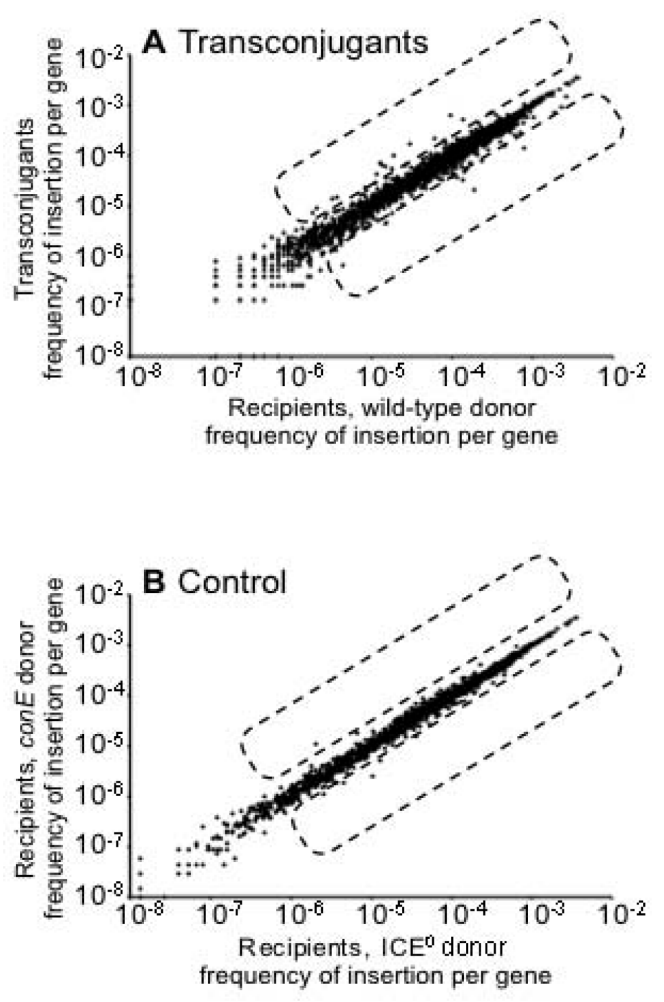

Figure 1.

Tn-seq analysis to identify genes in recipients that affect acquisition of ICEBs 1 . The frequencies of transposon insertions in annotated genes in B. subtilis in different pools from the genetic screen are compared. Each dot represents a gene. The numbers on each axis represent the frequency of transposon insertions in a given gene in the indicated pool as a fraction of the total insertions sequenced from that pool. Dashed boxes are used to visually approximate the criteria used to identify candidate genes.

A. The frequency of transposon insertions in each gene in the transconjugant population (Y axis) plotted versus the recipient population from the same mating, irrespective of ICEBs 1 acquisition ( $\mathrm{X}$ axis).

B. The frequency of transposon insertions in each gene in the recipient population from a mock-mating with the conjugation-defective donor MMB963 (Y axis) plotted versus the recipient population from a mock-mating with the ICE $B s I^{0}$ donor JMA222 (X axis). 


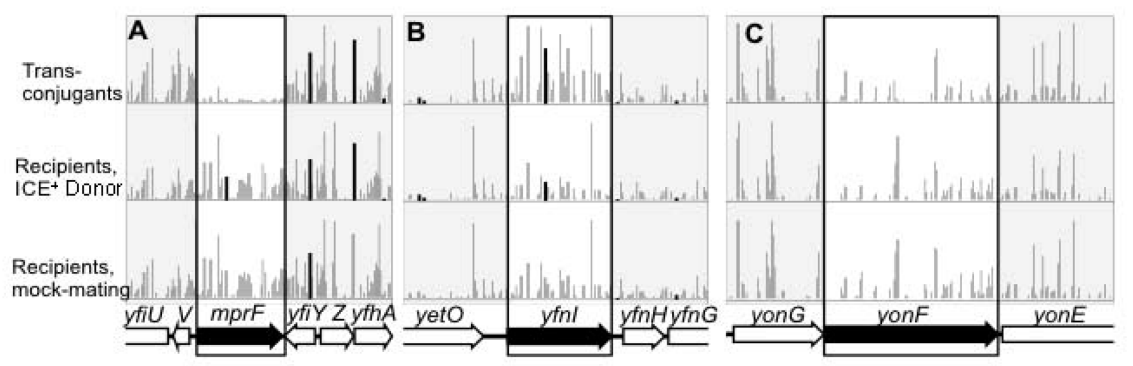

Figure 2.

Locations of transposon insertions in representative candidate genes. Each histogram shows the location and frequency of transposon insertions in the indicated genome region. $\mathbf{A}$.

$m p r F$; B. $y f n I$; C. yonF. The top row shows insertions in the transconjugant, the middle and bottom rows show insertions in the indicated control pools. Middle: Recipients from mating with WT (wild type) donor (KM250); bottom: recipients from a mock-mating with ICEBs $1^{0}$ donor (JMA222). The location on the $\mathrm{X}$ axis represents the location on the chromosome, and the height of each line represents the number of transposon insertions at that location, relative to the number of insertions at other locations in the region. The boxed regions denote the boundaries of genes of interest. The map on the bottom shows the location and orientation of genes. The gene of interest is filled in black. 


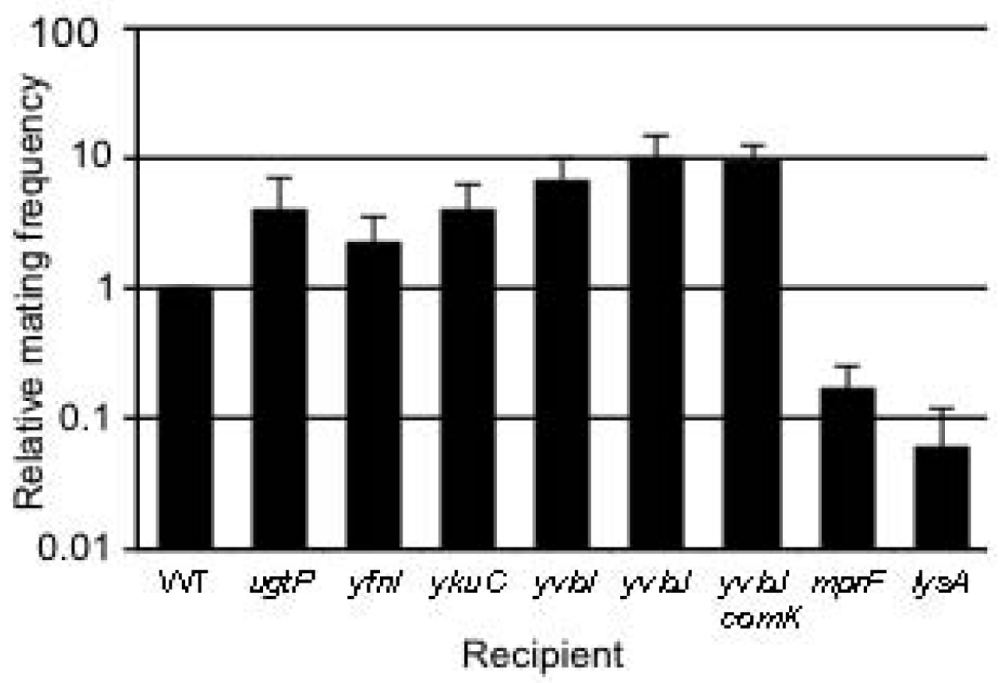

Figure 3.

Effects of mutations in the recipient on acquisition of ICEBs 1. Standard filter matings were performed using a wild type donor (KM250). Recipients were WT (CMJ161), or had null mutations in ugtP (CMJ83); yfnI (CMJ44); ykuC (CMJ46); yvbI (CMJ309); yvbJ (CMJ153); $y v b J$ and $\operatorname{comK}$ (CMJ179); mprF (CMJ162); lysA (CMJ335, grown with $40 \mu \mathrm{g} / \mathrm{ml}$ lysine). The relative mating frequency (y-axis) is the number of transconjugants per donor of the indicated strain normalized to that of wild type. The wild type mating efficiency was 0.048 $\left(4.8^{\circ}\right)$ transconjugants per donor \pm 0.053 (standard deviation). Graphs show means and standard deviation from $\geq 3$ experiments. For all mutants, $p \leq 0.05$, $t$-test, indicating that the conjugation frequency of each mutant is likely to be different from that of wild type. 

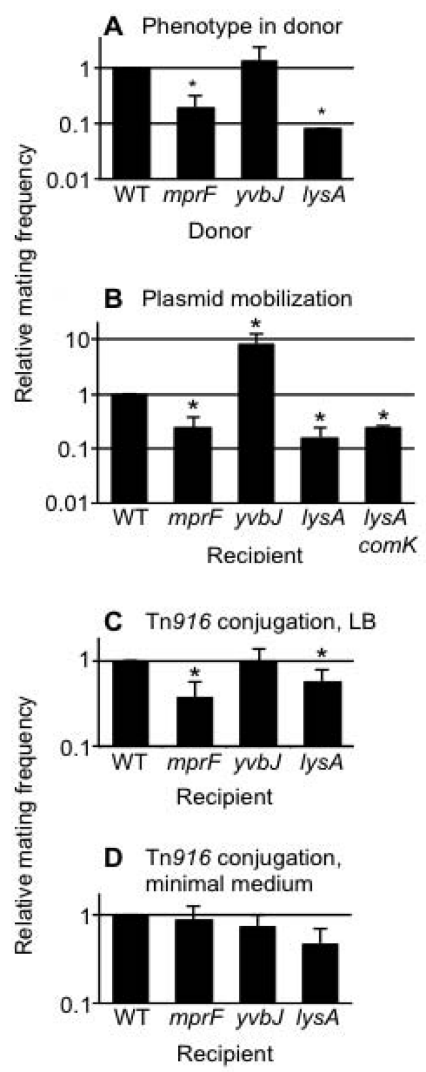

Figure 4.

Effects of host mutations on conjugation and plasmid mobilization. Mutants were tested in standard filter matings for their phenotype on the ability of a donor to deliver ICEBs 1 .

Relative mating frequencies are presented as a fraction of that of wild type donor and wild type recipient, as described for Fig. 3. Data presented are the averages \pm standard deviation from $\geq 3$ experiments. Asterisks above bars indicate a $p$ value $₫ 0.05$ in a $t$-test.

A. The indicated mutations were present in donor and ICEBs 1 was transferred to wild type recipients (CAL89). Donors strains were WT (KM250), or had null mutations in $m p r F$ (CMJ323), yvbJ (CMJ186), or lysA (CMJ351, grown with $40 \mu \mathrm{g} / \mathrm{ml}$ lysine). The average and standard deviation of mating with the wild type donor was $0.019 \pm 0.036$ transconjugants per donor.

B. Mobilization of pC194 by ICEBs 1 into mutant recipients. A strain (CMJ300) containing ICEBs 1 and pC194 was used as donor. Recipients were WT (CMJ161) or had null mutations in mprF (CMJ162), yvbJ (CMJ153), lysA (CMJ335) or lysA and comK (CMJ386). lysA mutants were grown in medium supplemented with $40 \mu \mathrm{g} / \mathrm{ml}$ lysine. Average and standard deviation of mobilization of pC194 into the WT recipient was $0.0045 \pm 0.0030$.

C, D. Transfer of Tn916 into mutant recipients. Donors containing Tn916 (CM253) and indicated recipients were grown in $(\mathbf{C})$ LB medium or (D) minimal medium prior to mating. Recipients were WT (CAL89) or had null mutations in $m p r F$ (CMJ162), yvbJ (CMJ153) or lysA (CMJ335, grown with $40 \mu \mathrm{g} / \mathrm{ml}$ lysine). Average and standard deviation of transfer of Tn916 into the WT recipient was $0.00025 \pm 0.00010$ for cells grown in LB and $0.00016 \pm$ 0.00006 for cells grown in minimal medium. 


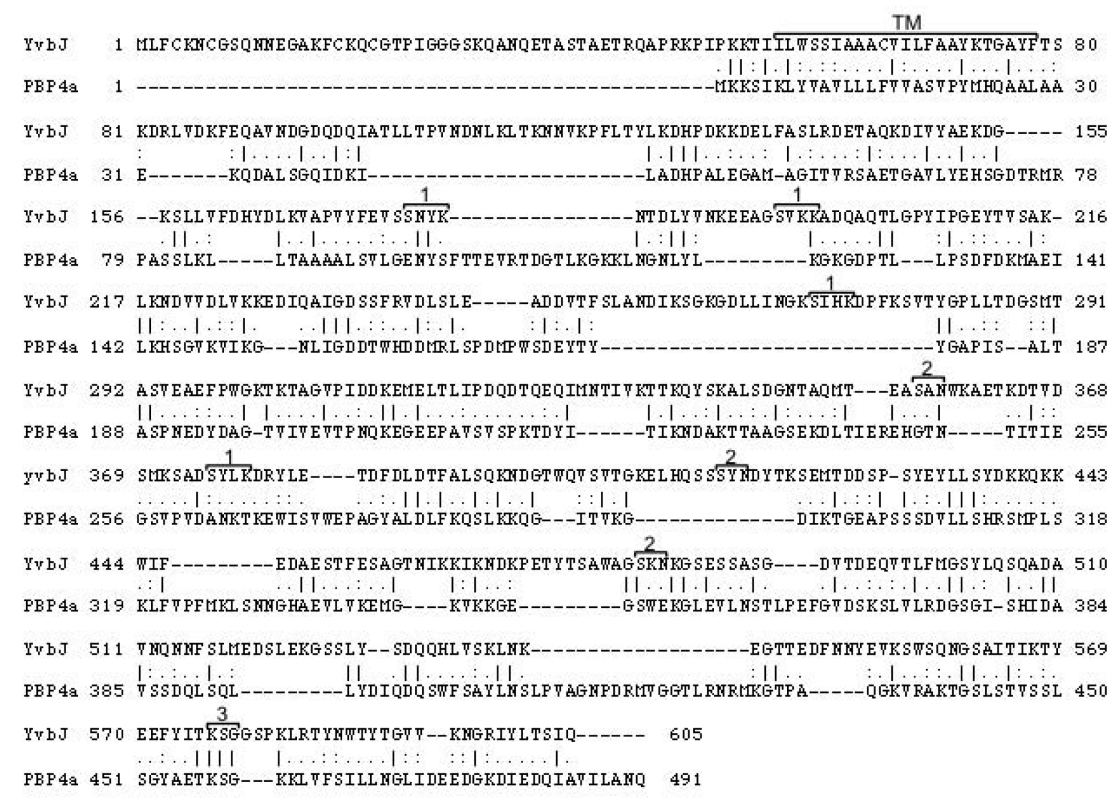

Figure 5.

YvbJ is paralogous to PBP4a. A global alignment between YvbJ and PBP4a is shown. Features shown include: the transmembrane domain (TM) predicted by TMHMM and sequence signatures of the penicilloyl serine transferases superfamily: 1: SxxK motif; 2: (S/ Y)xN motif; 3: K(T/S)G motif. 
Table 1

Genes identified by Tn-seq in recipients that are candidates for affecting acquisition of ICEBs 1 .

\begin{tabular}{|c|c|c|c|c|}
\hline Gene $^{l}$ & Strain & Tn-seq ${ }^{2}$ & Null $^{3}$ & Protein function/comments \\
\hline ugtP & CMJ83 & $\begin{array}{l}\text { Up } 2.9 \\
(1228)\end{array}$ & Up & Phospholipid synthetase -lipoteichoic acids (Jorasch et al., 1998) \\
\hline $\begin{array}{l}y f n I \\
\text { (ltaSA) }\end{array}$ & CMJ44 & $\begin{array}{l}\text { Up } 2.4 \\
(19858)\end{array}$ & Up & $\begin{array}{l}\text { Phospholipid synthetase-lipoteichoic acids } \\
\text { (Wormann et al., 2011) }\end{array}$ \\
\hline$y k u C$ & CMJ46 & $\begin{array}{l}\text { Up } 2.4 \\
(6066)\end{array}$ & Up & $\begin{array}{l}\text { Unknown, MFS superfamily, which includes trans- } \\
\text { membrane transporters with a variety of } \\
\text { mechanisms and substrate specificities }\end{array}$ \\
\hline$y v b I$ & CMJ309 & $\begin{array}{l}\text { Up } 5.5 \\
(6789)\end{array}$ & Up & Unknown \\
\hline$y v b J$ & CMJ153 & $\begin{array}{l}\text { Up } 2.7 \\
(16226)\end{array}$ & Up & Unknown; similar to PBPs (Fig. 5) \\
\hline$m p r F$ & CMJ162 & $\begin{array}{l}\text { Down } \\
0.15(827)\end{array}$ & Down & $\begin{array}{l}\text { Phospholipid synthetase- lysylphosphatidylglycerol } \\
\text { (Peschel et al., 2001) }\end{array}$ \\
\hline lysA & CMJ335 & $\begin{array}{l}\text { Down } \\
0.33(28)\end{array}$ & Down & Lysine synthesis (Yamamoto et al., 1991) \\
\hline dnaJ & CMJ171 & $\begin{array}{l}\mathrm{Up} 2.3 \\
(881)\end{array}$ & No & Protein folding chaperone \\
\hline$e c s B$ & CMJ170 & Up 2.8 (1301) & No & $\begin{array}{l}\text { Hydrophobic component of an } \mathrm{ABC} \text { transporter that } \\
\text { affects protein secretion (Leskela et al., 1996) }\end{array}$ \\
\hline $\begin{array}{l}h p r \\
(\operatorname{scoC})\end{array}$ & CMJ33 & $\begin{array}{l}\text { Up } 6.7 \\
(1828)\end{array}$ & No & $\begin{array}{l}\text { Transcriptional regulator, transition state regulator } \\
\text { (Perego \& Hoch, 1988) }\end{array}$ \\
\hline$k t r D$ & CMJ167 & $\begin{array}{l}\text { Down } \\
0.46(369)\end{array}$ & No & $\begin{array}{l}\text { Membrane subunit of KtrCD potassium uptake } \\
\text { system (Holtmann } \text { et al., 2003) }\end{array}$ \\
\hline pbpA & CMJ84 & $\begin{array}{l}\text { Up } 3.1 \\
(2027)\end{array}$ & No & PBP/cell wall synthesis (Murray et al., 1998) \\
\hline $\operatorname{pbpD}$ & CMJ85 & $\begin{array}{l}\text { Up } 2.5 \\
(3451)\end{array}$ & No & PBP/cell wall synthesis (Popham \& Setlow, 1994) \\
\hline $\operatorname{pcr} B$ & CMJ72 & $\begin{array}{l}\text { Down } \\
0.47(467)\end{array}$ & No & $\begin{array}{l}\text { In vitro, PcrB can catalyze a linkage of fatty acids } \\
\text { and phospholipids typical of archaeal membranes } \\
\text { (Guldan } \text { et al., 2011). Physiological consequence of } \\
\text { this in } B \text {. subtilis is not known. PcrB is located in an } \\
\text { operon upstream of } p c r A \text { and } \operatorname{lig} A \text {, both essential. }\end{array}$ \\
\hline $\begin{array}{l}\text { scuA } \\
(\text { sco })\end{array}$ & CMJ168 & $\begin{array}{l}\text { Up } 2.1 \\
(2421)\end{array}$ & No & $\begin{array}{l}\text { Membrane protein that delivers } \mathrm{Cu} \text { to a copper } \\
\text { center of cytochrome oxidase (Mattatall } \text { et al., 2000) }\end{array}$ \\
\hline $\begin{array}{l}\text { walH } \\
(y y c H)\end{array}$ & CMJ69 & $\begin{array}{l}\text { Up } 3.3 \\
(1001)\end{array}$ & No & $\begin{array}{l}\text { Regulates WalK/R (YycF/G) 2-component system } \\
\text { (Szurmant } \text { et al., 2005) }\end{array}$ \\
\hline$y h g E$ & CMJ70 & $\begin{array}{l}\text { Down } \\
0.43 \\
(2590) \\
\end{array}$ & No & $\begin{array}{l}\text { Unknown, predicted to contain } 5 \text { transmembrane } \\
\text { domains and a MFS domain (see } y k u C \text {, above) }\end{array}$ \\
\hline yonF $F^{4}$ & $\begin{array}{l}\text { CMJ67; } \\
\text { CMJ155 }\end{array}$ & $\begin{array}{l}\text { Down } \\
0.55 \\
(1491)\end{array}$ & No & Unknown protein encoded by lysogenic phage SPB \\
\hline$y v k N$ & CMJ65 & $\begin{array}{l}\text { Up } 2.3 \\
(5204)\end{array}$ & No & Unknown, no conserved domains \\
\hline
\end{tabular}

${ }^{1}$ The 19 candidate genes that were identified by increased or decreased frequency of insertions in transconjugants are indicated. Alternate gene names are shown in parentheses. Genes with verified phenotypes are listed first, followed by genes that did not have a robust reproducible phenotype listed alphabetically.

${ }^{2}$ In the Tn-seq column, "Up" and "Down" indicate the predicted phenotypes caused by null mutations in the indicated gene. The predictions were based on the Tn-seq results (Fig. 1) and the average change in insertion frequency in the transconjugant population compared to control 
populations, which is given as the first number (derived, in part, from data presented in Fig. 1A). The number of transposon insertions in the indicated gene in the transconjugant population is given in parentheses. Genes with more insertions (up; e.g., $y v b J$ ) in the transconjugant population were predicted to somehow limit conjugation and a null mutation should cause an increase in conjugation. Conversely, genes with fewer insertions (down; e.g., $m p r F$ ) in the transconjugant population were predicted to somehow stimulate conjugation and a null mutation should cause a decrease in conjugation.

${ }^{3}$ In the Null column, Up and Down indicate the phenotype caused by a null mutation in the indicated gene. "No" indicates that the null mutation(s) did not cause a reproducible detectable change in conjugation efficiency.

${ }^{4}$ CMJ67 and CMJ155 carry different null alleles of yonF (Experimental procedures) 


\section{Table 2}

B. subtilis strains used.

\begin{tabular}{|c|c|}
\hline Strain & Genotype \\
\hline BOSE985 & $\operatorname{trp}$ phe ICEBs $1^{0}$, amyE::\{Pxyl-rapI cat $\}$ (Berkmen et al., 2010; Menard \& Grossman, 2013) \\
\hline BS49 & metB5, hisA1, thr-5, Tn916 (Christie et al., 1987; Haraldsen \& Sonenshein, 2003) \\
\hline CAL85 & trp phe $\operatorname{ICE} B s 1^{0}$, str84 (Auchtung et al., 2005) \\
\hline CAL89 & trp phe ICE $B s 1^{0}$, str84, comK::spc (Auchtung et al., 2005) \\
\hline CAL419 & trp phe ICEBs $1^{0}$, str84, comK::cat (Auchtung et al., 2005) \\
\hline CMJ33 & trp phe ICEBs $1^{0}$, hpr::cat, amyE::\{lacI spc $\}$ \\
\hline CMJ44 & trp phe $\operatorname{ICEB} s 1^{0}, \Delta y f n I 44:: s p c$ \\
\hline CMJ46 & $\operatorname{trp}$ phe $\mathrm{ICE} B s 1^{0}, \Delta y k u C 46:: s p c$ \\
\hline CMJ65 & $\operatorname{trp} p h e \mathrm{ICE} B s 1^{0}, \Delta y v k N 65:: s p c$ \\
\hline CMJ67 & $\operatorname{trp}$ phe $\mathrm{ICEB} B 1^{0}, \Delta y o n F 67:: s p c$ \\
\hline CMJ69 & trp phe ICEBs $1^{0}, \Delta$ walH69::spc \\
\hline CMJ70 & trp phe ICEBs $1^{0}, \Delta y g h E 70:: s p c$ \\
\hline $\mathrm{CMJ} 72$ & trp phe ICEBs $1^{0}, \Delta p c r B 72:: s p c$ \\
\hline CMJ73 & trp phe $\operatorname{ICE} B s 1^{0}, \Delta l y s A 73:: m l s$ \\
\hline CMJ83 & trp phe ICEBs $1^{0}$, ugtP::mls, amyE::\{lacI spc $\}$ \\
\hline CMJ84 & trp phe $\mathrm{ICE} B s 1^{0}$, pbpA::erm \\
\hline CMJ85 & trp phe ICEBs $1^{0}$, pbpD::erm \\
\hline CMJ124 & trp phe ICEBs $1^{0}, \Delta m p r F 124:: m l s$ \\
\hline CMJ127 & trp phe amyE:: $\{$ Pxyl-rapI cat $\}, \Delta($ rapI-phrI $) 342:: k a n, \Delta m p r F 124:: m l s$ \\
\hline CMJ153 & trp phe ICEBs $1^{0}, \Delta y v b J 153:: s p c$ \\
\hline CMJ154 & trp phe ICEBs $1^{0}, \Delta y v b I J 154:: s p c$ \\
\hline CMJ155 & trp phe ICEBs $1^{0}$, syonF155::spc \\
\hline CMJ161 & $\operatorname{trp}$ phe $\mathrm{ICE} B s 1^{0}$, amyE::spc \\
\hline CMJ162 & trp phe ICEBs $1^{0}, \Delta m p r F 162:: s p c$ \\
\hline CMJ167 & trp phe $\mathrm{ICE} B s 1^{0}, \Delta k \operatorname{trD} 167:: s p c$ \\
\hline CMJ168 & trp phe $\operatorname{ICE} B s 1^{0}, \Delta s c u A 168:: s p c$ \\
\hline CMJ170 & trp phe $\operatorname{ICE} B s 1^{0}, \Delta e c s B 170:: s p c$ \\
\hline CMJ171 & trp phe ICEBs $1^{0}, \Delta d n a J 171:: s p c$ \\
\hline CMJ175 & trp phe $\mathrm{ICE} B s 1^{0}, \Delta y v b J 175:: m l s$ \\
\hline CMJ179 & trp phe ICEBs $1^{0}, \Delta y v b J 175:: m l s$, comK::cat \\
\hline CMJ186 & trp phe amyE:: $\{$ Pxyl-rapI cat $\}, \Delta($ rapI-phrI) $342:: k a n, \Delta y v b J 175:: m l s$ \\
\hline $\mathrm{CMJ} 236$ & trp phe $\operatorname{ICE} B s 1^{0}, \Delta y v b J 175:: m l s, \Delta y k u C 46:: s p c$ \\
\hline $\mathrm{CMJ} 253$ & trp phe ICE $B s 1^{0}, \operatorname{Tn} 916$ (from BS49) \\
\hline $\mathrm{CMJ} 288$ & trp phe $\operatorname{ICE} B s 1^{0}$, amyE::spc, dacA::cat \\
\hline CMJ289 & trp phe $\operatorname{ICE} B s 1^{0}$, amyE::spc, pbpC::cat \\
\hline
\end{tabular}




\begin{tabular}{|c|c|}
\hline Strain & Genotype \\
\hline CMJ290 & trp phe $\operatorname{ICE} B s 1^{0}, \Delta y v b J 175:: m l s$, amyE::spc, dacA::cat \\
\hline CMJ291 & trp phe ICE $B s 1^{0}, \Delta y v b J 175:: m l s$, amyE::spc, pbpC::cat \\
\hline CMJ292 & trp phe ICE $B s 1^{0}, p b p H:: s p c$ \\
\hline CMJ293 & $\operatorname{trp}$ phe $\operatorname{ICE} B s 1^{0}$, ponA::spc \\
\hline CMJ294 & trp phe ICEBs $1^{0}$, dacC::spc \\
\hline CMJ295 & trp phe ICEB $s 1^{0}, \Delta y v b J 175:: m l s, p b p H:: s p c$ \\
\hline CMJ296 & trp phe ICE $B s 1^{0}, \Delta y v b J 175:: m l s$, ponA::spc \\
\hline CMJ297 & trp phe $\operatorname{ICE} B s 1^{0}, \Delta y v b J 175:: m l s$, dacC::spc \\
\hline CMJ300 & trp phe amyE::\{Pxyl-rapI mls\}, $\Delta($ rapI-phrI)342::kan, pC194 (cat) \\
\hline CMJ307 & trp phe ICEBs $1^{0}, \Delta y v b J 307::$ lox-cat \\
\hline CMJ309 & trp phe ICEBs $1^{0}, \Delta y v b I 309:: s p c$ \\
\hline CMJ314 & trp phe ICE $B s 1^{0}, \Delta d a c C 314:: s p c$ \\
\hline CMJ323 & trp phe amyE:: $\{$ Pxyl-rapI cat $\}, \Delta($ rapI-phrI) $342:: k a n, \Delta m p r F 162:: s p c$ \\
\hline CMJ327 & trp phe ICE $B s 1^{0}, \Delta p b p D$ (unmarked), ywhE::kan, pbpF::mls \\
\hline CMJ335 & trp phe ICE $B s 1^{0}, \Delta l y s A 73:: m l s$, amyE:: $\{$ lacI spc $\}$ \\
\hline CMJ351 & trp phe amyE:: $\{$ Pxyl-rapI cat $\}, \Delta($ rapI-phrI $) 342:: k a n, \Delta l y s A 73:: m l s$ \\
\hline CMJ353 & $\begin{array}{l}\operatorname{trp} p h e \text { ICE } B s 1^{0}, \Delta p b p D \text { (unmarked), } \Delta y v b J 307 \text { (unmarked), ywhE::kan, } \\
\text { pbpF::mls }\end{array}$ \\
\hline CMJ375 & $\begin{array}{l}\operatorname{trp} p h e \text { ICE } B s 1^{0}, \Delta p b p D \text { (unmarked), } \Delta y v b J 307 \text { (unmarked), ywhE::kan, } \\
\text { pbpF::mls, ponA ::spc }\end{array}$ \\
\hline CMJ386 & trp phe ICE $B s 1^{0}, \Delta l y s A 73:: m l s$, comK::spc \\
\hline CMJ514 & trp phe ICEBs $1^{0}, \Delta y v b J 153:: s p c$, ugtP::mls \\
\hline CU1065 & $\operatorname{trp} C 2, \mathrm{SPB}^{\mathrm{s}}$ (Zahler et al., 1977) \\
\hline DPVB49 & PS832, $\Delta p b p D$ (unmarked), ywhE::kan, pbpF:::mls (McPherson et al., 2001) \\
\hline DPVB133 & PS832, pbpH::spc (Wei et al., 2003) \\
\hline DPVB203 & PS832, pbpA::erm (Wei et al., 2003) \\
\hline HB5346 & CU1065, ugtP::mls (Salzberg \& Helmann, 2008) \\
\hline IS708 & hisA1, leuA8, metB5, hpr::cat (Wray et al., 1994) \\
\hline JMA222 & trp phe ICE $B s 1^{0}$ (Auchtung et al., 2005) \\
\hline KM250 & trp phe amyE:: $\{$ Pxyl-rapI cat $\}, \Delta($ rapI-phrI) $342:: k a n$ (Menard \& Grossman, 2013) \\
\hline MMB963 & $\begin{array}{l}\text { trp phe amyE:: }\{\text { Pxyl-rapI cat }\}, \Delta(\text { rapI-phrI) } 342:: k a n, \text { conE } \Delta(88-808) \text { (unmarked) } \\
\text { (Berkmen et al., 2010) }\end{array}$ \\
\hline PS832 & protrotroph; derived from B. subtilis 168 (Popham \& Setlow, 1994) \\
\hline PS1900 & PS832, dacA::cat (Popham et al., 1996) \\
\hline PS2022 & PS832, pbpD::erm (Popham \& Setlow, 1994) \\
\hline PS2062 & PS832, ponA::spc (Popham \& Setlow, 1995) \\
\hline PS2324 & PS832, dacC::spc (Pedersen et al., 1998) \\
\hline PS2352 & PS832, pbpC::cat (Murray et al., 1996) \\
\hline
\end{tabular}

